Portland State University

PDXScholar

Dissertations and Theses

Dissertations and Theses

6-7-1976

\title{
Supergraphics in the Portland Environment
}

John Earl Allgood

Portland State University

Follow this and additional works at: https://pdxscholar.library.pdx.edu/open_access_etds

Part of the Art Education Commons, and the Interdisciplinary Arts and Media Commons Let us know how access to this document benefits you.

\section{Recommended Citation}

Allgood, John Earl, "Supergraphics in the Portland Environment" (1976). Dissertations and Theses. Paper 2439.

https://doi.org/10.15760/etd.2434

This Thesis is brought to you for free and open access. It has been accepted for inclusion in Dissertations and Theses by an authorized administrator of PDXScholar. Please contact us if we can make this document more accessible: pdxscholar@pdx.edu. 
AN ABSTRACT OF THE THESIS OF John Earl Allgood for the Master of Science in Teaching presented June 7, 1976.

Title: Supergraphics in the Portland Environment.

APPROVED BY MEMBER OF THE THESIS COMMITTEE:

Robert Morton, Chairman

J6an Gleser : T.

Fréd Kline

It is my purpose in this thes is to explore supergraphice in the Portland area. I intend this thesis to be used as a source book for teachers wishing to Implement supergraphics programs in their schools. I plan to divide my thesis into two areas: First, a survey of supergraphics in the Portland environment, and second, a survey of Portland area schools that have implemented supergraphic projects or programs. 
A substantial portion of the information compiled for this thesis comes from conversations with Portland area graphic designers, architects and teachers. I have included photographs of what I consider to be good examples of Portland area supergraphics. It is my hope that this thesis w111 be a valuable source of information for teachers who are interested in beginning a supergraphics program in their schools. 
SUPERGRAPHICS IN THE PORTLAND ENVIRONMENT

by

JOHN EARL ALLGOOD

A thesis submitted in partial fulfillment of the requirements for the degree of

MASTER OF SCIENCE in TEACHING

in

ART

Portland State University

1976 
TO THE OFFICE OF GRADUATE STUDIES:

The members of the Committee approve the theols of

John Earl Allgood presented June 7,1976.

Robert Morton, Chairman

T Jean GIazer

10

Fred Kline

APPROVED:

Leonard Kimbre11, Head, Art Department

Richhrd B.Halley, Acting Dean of Gradifte
Studies and Research 
TABLE OF CONTENTS

PAGE

LIST OF FIGURES

v

CHAPTER

I INTRODUCTION

Description of Supergraphics $\ldots \ldots \ldots \ldots \ldots \ldots \ldots$.

Att1tudes toward supergraphlcs $\ldots \ldots \ldots \ldots \ldots \ldots . . . .2$

Supergraphics as part of American Life ....... 3

II PORTLAND SUPERGRAPHICS

U.S. Bank Bullding, Crown Plaza ........... 5

Youngland Clothing store ................ 7

Portland State University $\ldots \ldots \ldots \ldots \ldots \ldots \ldots \ldots$

Banana Records $\ldots \ldots \ldots \ldots \ldots \ldots \ldots \ldots \ldots \ldots \ldots \ldots$

Tower-Tote Restaurant $\ldots \ldots \ldots \ldots \ldots \ldots \ldots \ldots \ldots$

Menpower Offlces, Marylhurst $\ldots \ldots \ldots \ldots \ldots \ldots \ldots .13$

Campus $\ldots \ldots \ldots \ldots \ldots \ldots \ldots \ldots \ldots \ldots \ldots \ldots \ldots \ldots \ldots$

John's Landing $\ldots \ldots \ldots \ldots \ldots \ldots \ldots \ldots \ldots \ldots \ldots \ldots$

Foster Hotel $\ldots \ldots \ldots \ldots \ldots \ldots \ldots \ldots \ldots \ldots \ldots \ldots, 16$ 
CHAPTER

PAGE

III SUPBRGRAPHICS IN PORTLAND SCHOOLS

Teacher-directed, student-designed approach ... 20

School Supergraphice with a thematic scheme .... 22

Student-initiated approsch $\ldots \ldots \ldots \ldots \ldots \ldots \ldots \ldots .27$

Artists-in-residence $\ldots \ldots \ldots \ldots \ldots \ldots \ldots \ldots \ldots \ldots \ldots .27$

FOOTNOTES ............................... 35

A IIST OF WORKS COMSULTED ................... 36 
LIST OF FIGURES

F IGURE

PAGE

1. Exterior, U.S. Bank ................... 5

2. Exterior, U.S. Bank with reflection of street. 6

3. Interior, Youngland Clothing store ......... 7

4. Interlor, Youngland Clothing store ......... 8

5. Interfor, Portland State University ......... 9

6. Exterior, Banana Records $\ldots \ldots \ldots \ldots \ldots \ldots \ldots \ldots .10$

7. Exterior Detail $\ldots \ldots \ldots \ldots \ldots \ldots \ldots \ldots \ldots \ldots \ldots \ldots$

8. Entrance, Tower-Tote Reataurant $\ldots \ldots \ldots \ldots \ldots \ldots \quad 12$

9. Interfor, Tower-Tote Restaurant ........... 12

10. Employee Dining Area ................. 13

11. Interior, Manpower Offices, Marylhurst Campus . 14

12. Entrance, John's Landing................. 15

13. Exterior, John's Landing ................ 15

14. Lobby, Foster Hotel .................. 16

15. Lobby, Foster Hotel $\ldots \ldots \ldots \ldots \ldots \ldots \ldots \ldots \ldots \ldots \ldots$

16. Interfor Hal1, Foster Hotel ............. 17

17. Exterior, Hanna Industries .............. 18

18. Exterior, Henna Industries ............... 19

19. Interior, West Linn High School ........... 21

20. Interior, West Linn High School $\ldots \ldots \ldots \ldots \ldots \ldots \ldots . . .21$ 
21. Entrance Arch, Weluga Jr. High School . . . . 22

22. French, Room, Walúge Jr. High School . . ... 23

23. Reading Center, Waluge Jr. HIgh School . . . 23

24. Hallway, Waluga Jr.High School . . . . . . . 24

25. Hallway, Waluga Jr. High School ......... 24

26. Hallway, Haluga Jr. High School ........ 25

27. Multimedia Center, Waluga Jr. High School , ... 25

28. Student Store, Waluga Jr. High School . . . . 26

29. Student Rest Rooms, Waluga Jr. High School ... 26

30. Library Colum, Orøgon City High School. . . : 28

31. Resource Centér, Oregon City High School . ... 28

32. Interior, Franklin High School . . . . . . 29

33. Interior, Franklin High School . . . . . 30

34. Interior, Franklin High School ......... 31

35. Cafeteria, Washington High School ....... 31

36. Deta11, Washington High School ........ 32

37. Auto Shop Exterior, Franklin High School . ... 33

38. Exterilor, Lakeridge High School . . . .... 34 


\section{CHAPTER I}

\section{INTRODUCTION}

The manipulation of architectural surfaces in order to make an interior or exterior surface more pleasing has always been with us in forms such as facades, frescos, stalned gless windows and bas-relief. In this century, the new medium of supergraphics has taken on apecial importance, where architecture ts burdened more by financial necessity than by aesthetics. Our modern bulldings have all too often taken the form of boringly repetitive megalithic super-structures. We feel more like insignificant ants than humang in the face of these gigantic ekyward-reaching blank slabs. Supergraphics has become an inexpensive means of breaking down these vast vertical planes into more pleasing and personal spaces. Supergraphics has also become a public medium, bringing architecture and art back to the people. Ilene Kressel, Northwest Beautification Project Coordinator, feels supergraphice has great potential because it takes art off the canvas and out of the museum and places it Into the world we face every day. It has become part of our environment. 1

Supergraphice has risen as a modern term for the application of paint to a large surface area with the purpose of disguising, giving direction to or modulating spacially negative spaces into more Interesting and informative postive ones. Supergraphics 
are found on interfor and exterior wall surfaces of offices, churches, schools, homes and industrial sites. They are found on cellings, floors, pillars, beams, the sides of automobiles, planes, trains, dam sites -- virtually any structure with a surface area where paint can be applied.

Because of the ease of application and inexpensive means of this art form, it has gotten to the point where almost anyone with a bucket of paint and a brush can create a supergraphics project. The vast size of supergraphics necessitates a great deal of consideration of the spacial relationships involved before the design is rendered and the paint applied. The degree of success in supergraphics has, unfortunately, suffered from a lack of asethetic concern and has been a source of anxiety for many professionals. It comes as no great surprise then that many professionals have disassociated themselves with the term "supergraphics". They feel it lumps them together with laymen who merely decorate the surfaces of walls and do not understand or care about the formal aesthetic considerations that a supergraphic project demands. Arvid Orbeck and Lou Ocepek are two professionals who are more fond of the term "Wall Graphics", a term formerly used to describe large graphic works on wall surfaces, that lacks the stigma associated with supergraphics. An eastern firm, Propper and Elman has chosen the term "archimedia" to describe 
supergraphics. According to Propper, archlmedla is "turning architectural elements and spaces into specific communications medla." 2

There are others that will embrace rather than disassociate themselves from the medium. Robert Venturi, and Steven Irenour will defend to the death what most of us feel to be some of our more disgusting displays of supergraphics and supergraphics-related mediums: our visual clutter of commercial signs, billboards and neon lights. Venturi feels that these are the mainstays of Americana, symbols of the American city. They are signs of life. Irenour maintains that too much design control creates a rather sterile environment: "We're telling other professionals how you can learn from things you hate." 3

I find that I must agree that the overcrowded messy city-scapes that we've learned to grudgingly live with do possess a certain magnetism. My own experiences with the "ideal" community of Columbia, Maryland resulted in an exasperated boredom. Columbia, Maryland is a new c1ty on the east coast that was developed as an answer to the complex problems of urban renewal. The 1dea is to build new cities instead of renovating old slums. Columbia was designed to be an aesthetic city, free of congestion with tightly controlled design elements. All utilities including telephone poles 
and television antennas are underground. Supergraphics there are limited to directional signs, which are specific in sizes, shapes and colors. Columbia is a very pleasing and orderly city to look at, but it gives one the uneasy feeling of visiting a cemetery.

There are many forms of art that are related to supergraphica closely enough to cause some confusion as to whether or not they come under the definition of supergraphics. Directional signs, murals and billboards could all be considered supergraphics under the right circumstances. Directional signs painted on the surface of a building, murals painted in a graphic way with the intention of disguising an "eye-sore" or directional billboards all come very close to being supergraphics, but might be listed under another heading. In such cases, it might be best to use terms such as supergraphicmural, supergraphic-sign or supergraphic-billboard.

I find supergraphics, despite the controversy surrounding it, to be an exciting, and visually stimulating medium. In my view, supergraphics is a lasting art form. In the future I feel, It will become as accepted as etching or ceramics. Supergraphics at its best is a fascinating and gratifying aesthetic experience. 


\section{PORTLAND SUPERGRAPHICS}

Despite Portland's restrictions on billboards and signs in the inner city, there are countless examples of supergraphics throughout the metropolitan area. One outstanding example of downtown supergraphics is Don Morgan's work at the U.S. Bank Building, Crown Plaza.

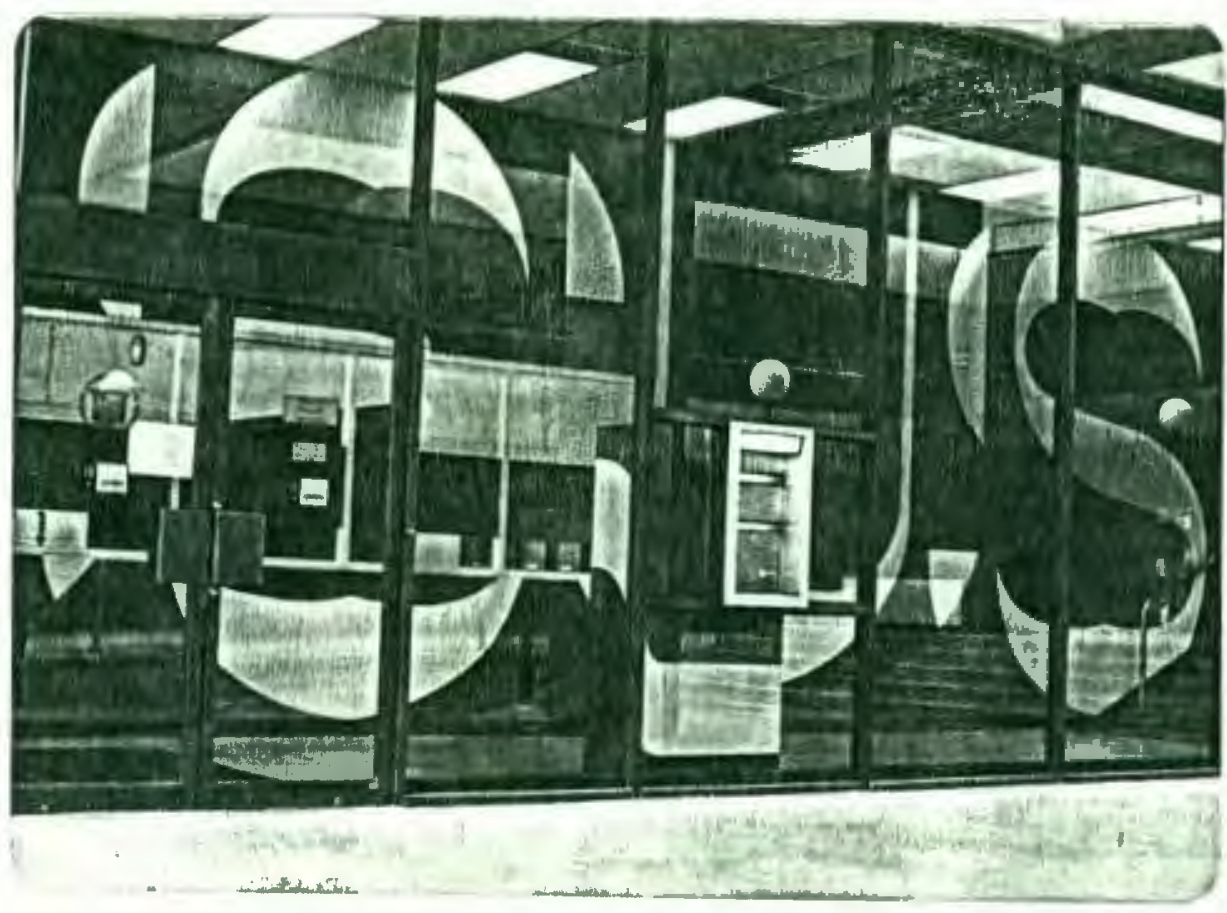

Figure 1. Exterior, U.S. Bank 
Mr. Morgan has worked out a crisp simple design by overlapping letter forms to create a striking and informative effect. It would be virtually impossible to walk into that building and believe you were in any place other than U.S. Bank. Mr. Morgan believes that design and color bear an important relationship to the function of the building.

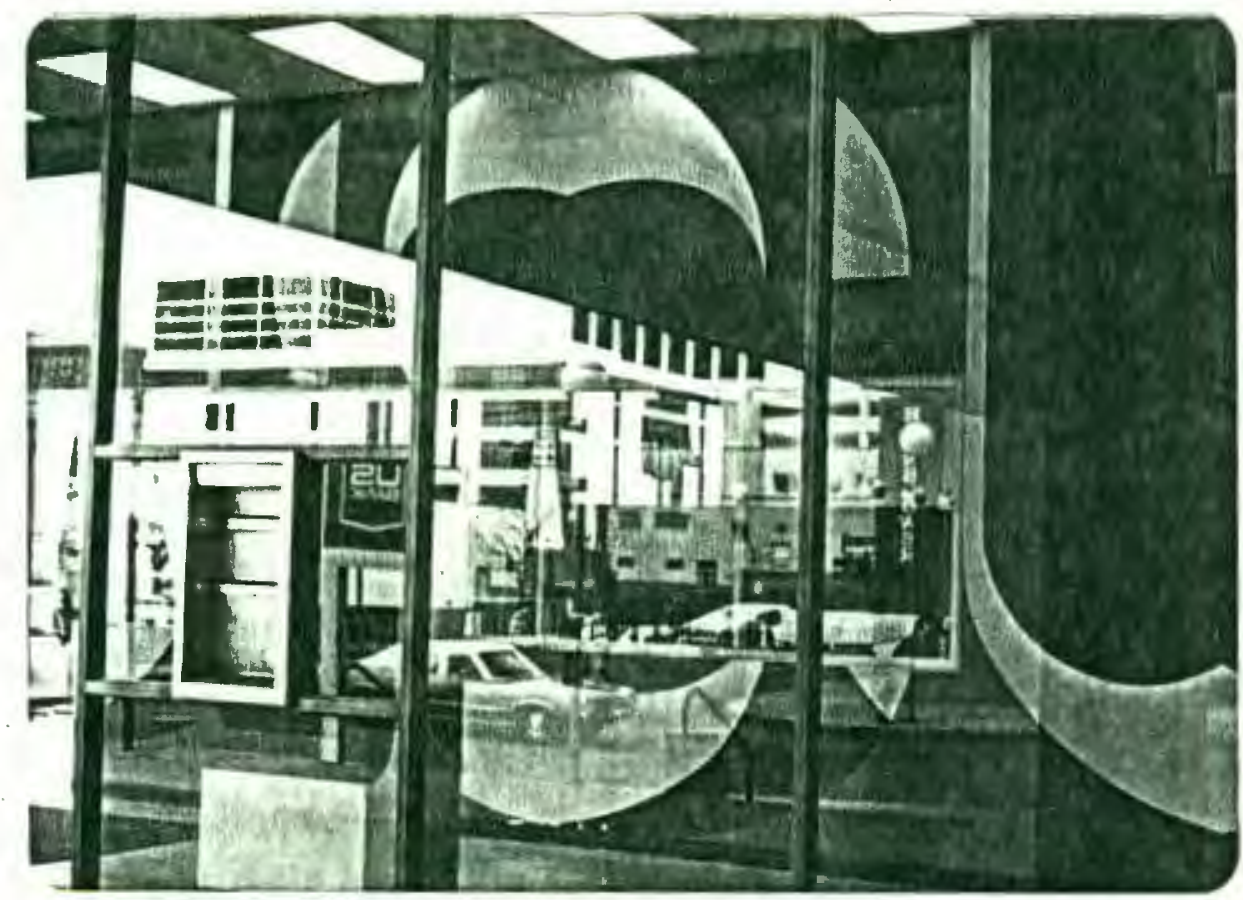

Figure 2. Exterior U.S. Bank with reflection of street. 
This is demonstrated by his work at a Youngland Clothing Store at 50 N.W. 23rd place. At Youngland Clothing Store, Mr. Morgan chose appropriate selections of color to cater to different age groups. For instance, he used soft colors in the infant wear department. The result was separate moods projected throughout the store to enhance the presentation of children's apparel.

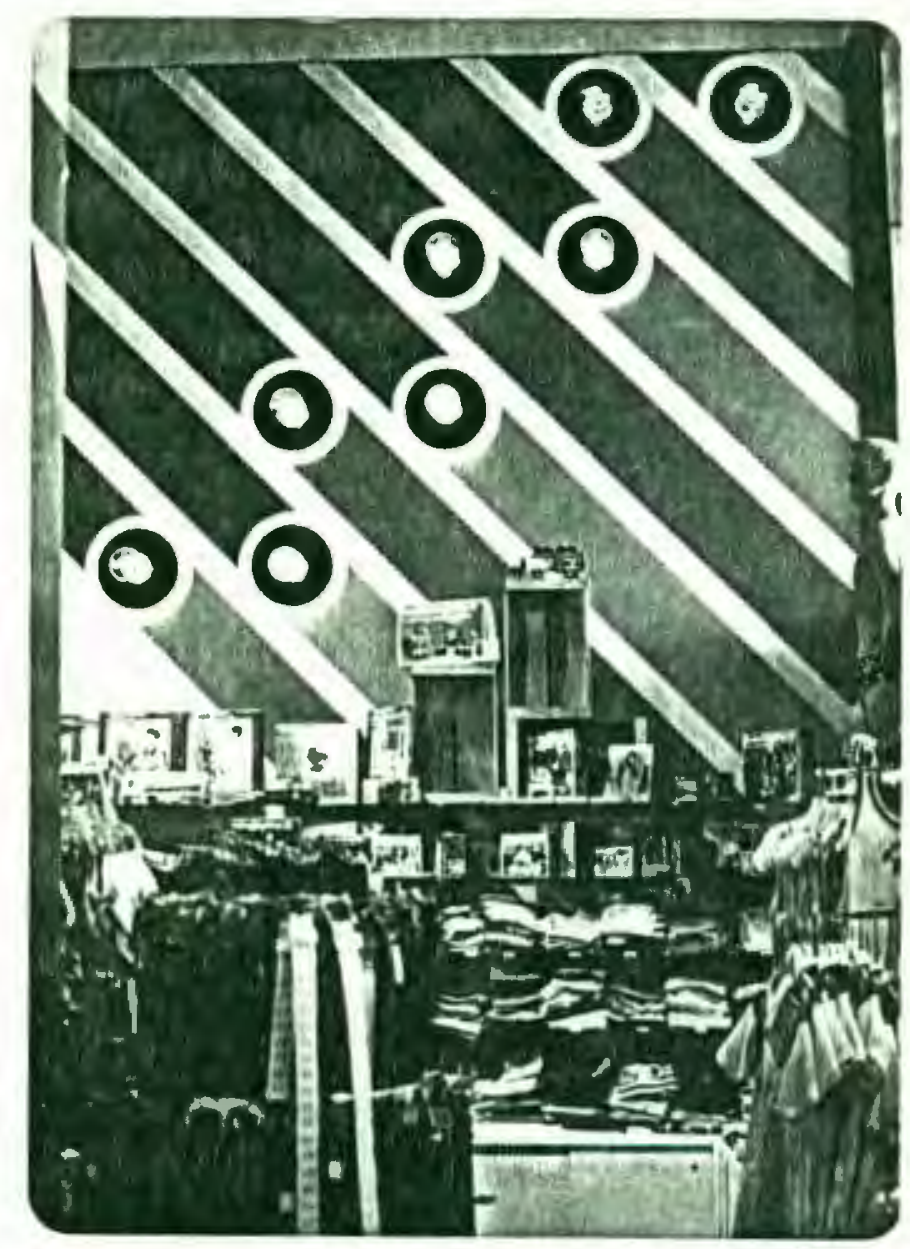

Figure 3. Interior, Youngland Clothing Store 


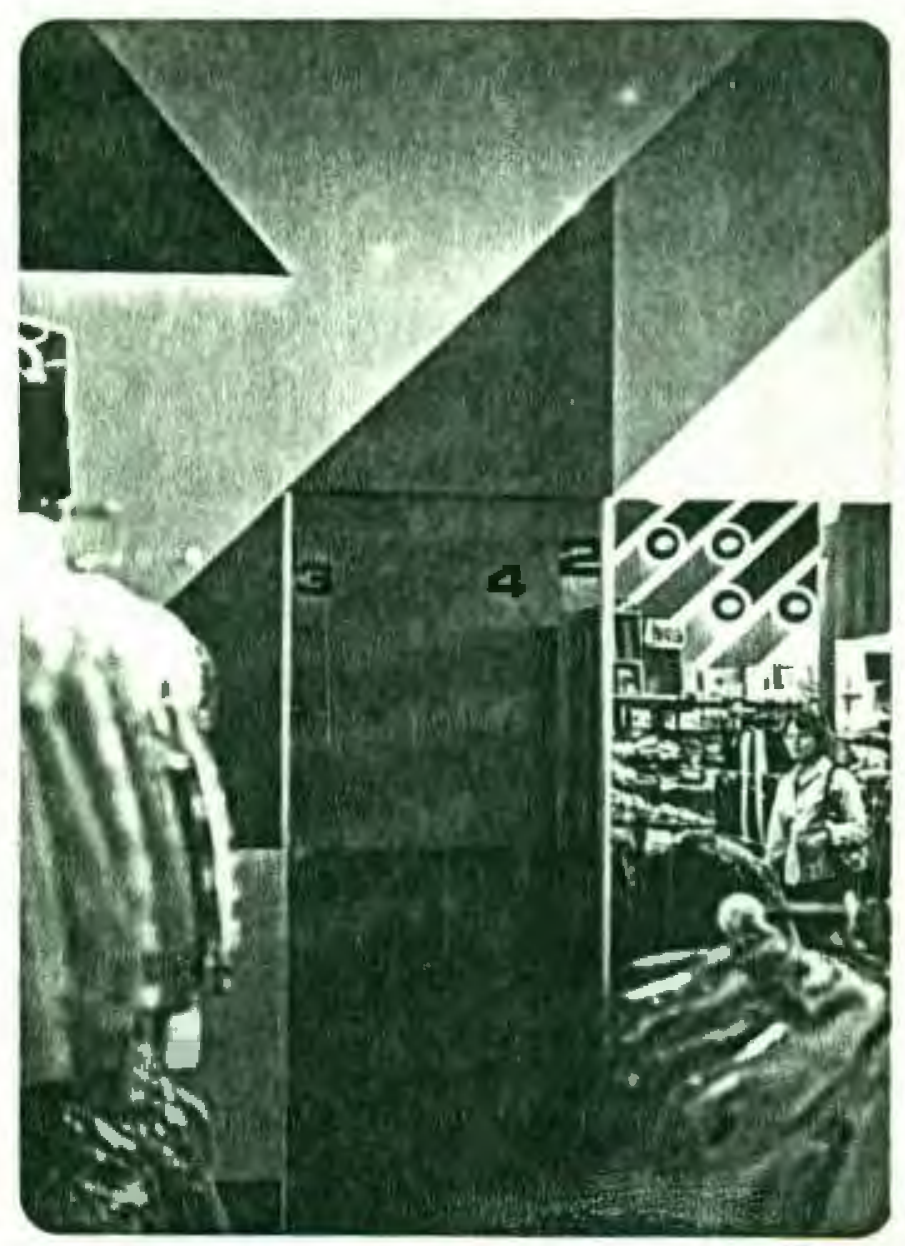

Figure 4. Interior, Youngland Clothing Store

Arvid Orbeck, who developed a unified design system to help students stumble their way through the confusing architecture at Portland State UnIversity, is very outspoken about the purpose of supergraphics. He belleves that supergraphics should be an extension of architectural form and should result in a harmony between the architecture and wall graphics. 


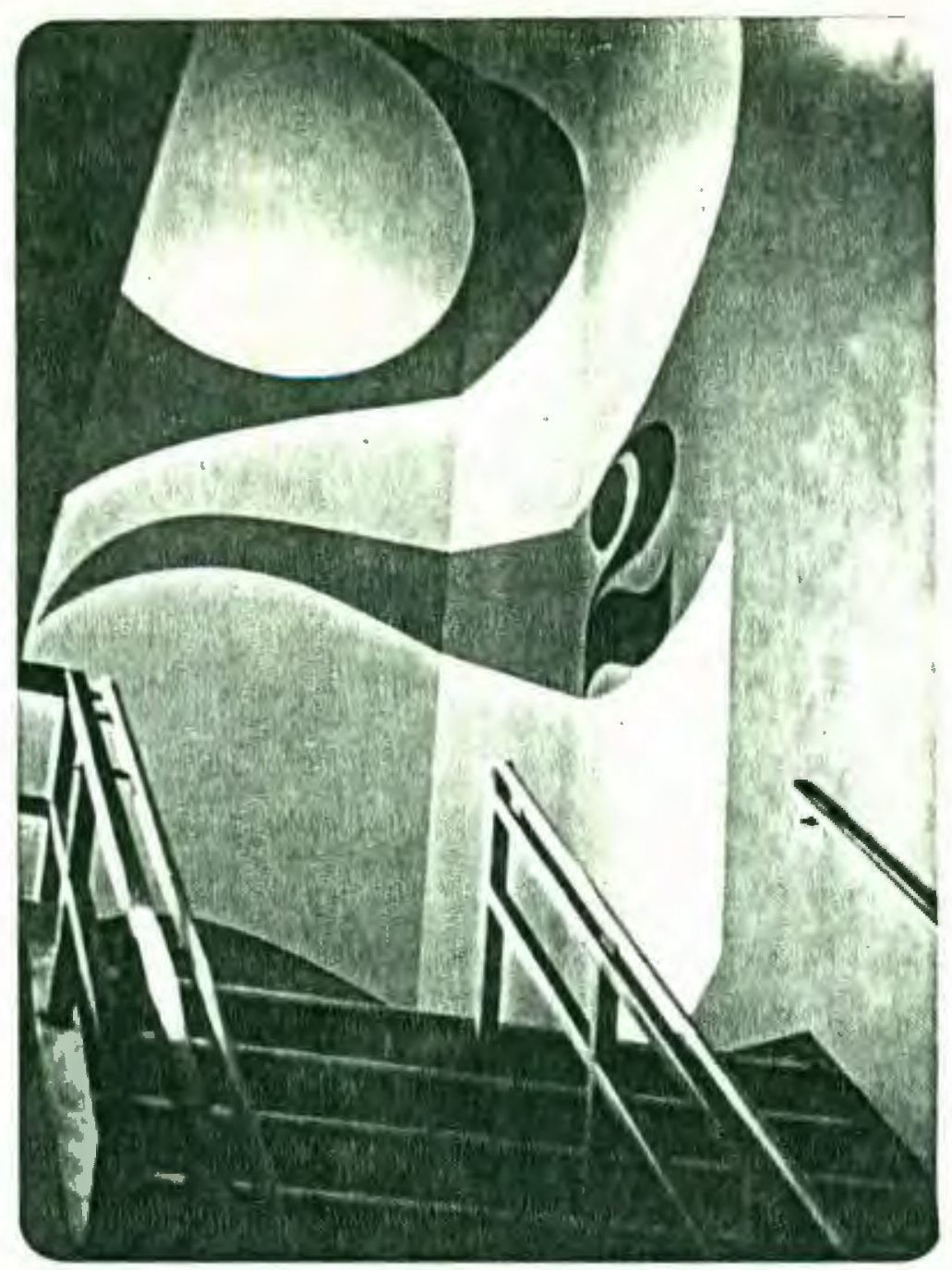

Figure 5. Interior, Portland State University

He described supergraphics as using space and contrasting forms in order to create opposing compositions. He sees supergraphics as being similar to a river in a landscape: It breaks up the space and makes it more interesting. His supergraphics at Portland State University were aimed at resolving the unreadability of the floor numbers and relating the large-sized graphics to the wall as part of an architectural shape. As a result, students can easily tell what floor they are on despite crowded situations and unusual connections between buildings. 
Dan Wilson has combined a painterly style with the supergraphics medium to give a combined mural-graphic effect in the vein of super realism. His work at Banana Records at S.W. Yamhill depicts familar recording artists unified by intersecting circles much like the shapes of records.

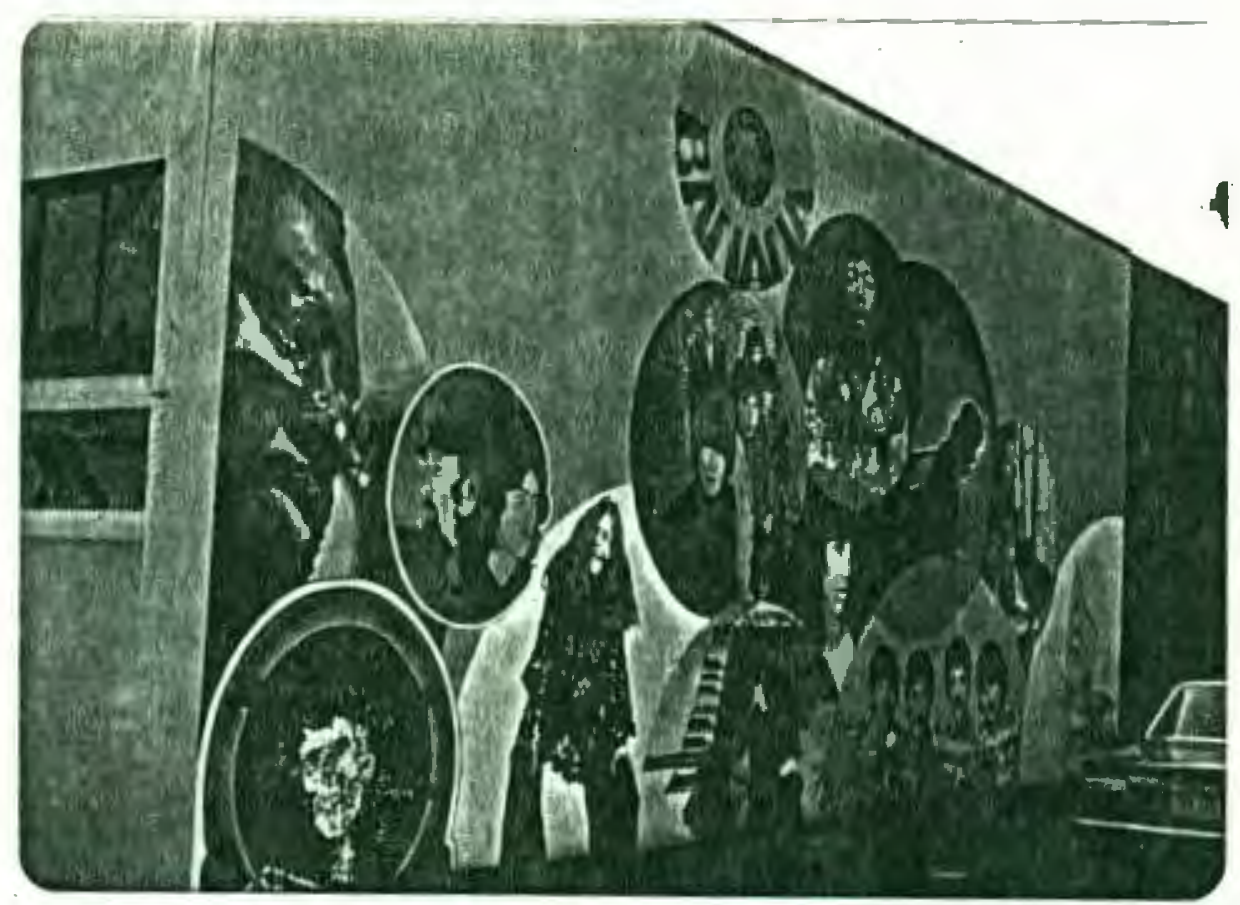

Figure 6. Exterior, Banana. Records

The overall effect is the conversion of a blank wall into an effective advertisment aimed specifically at young music enthusiasts. 


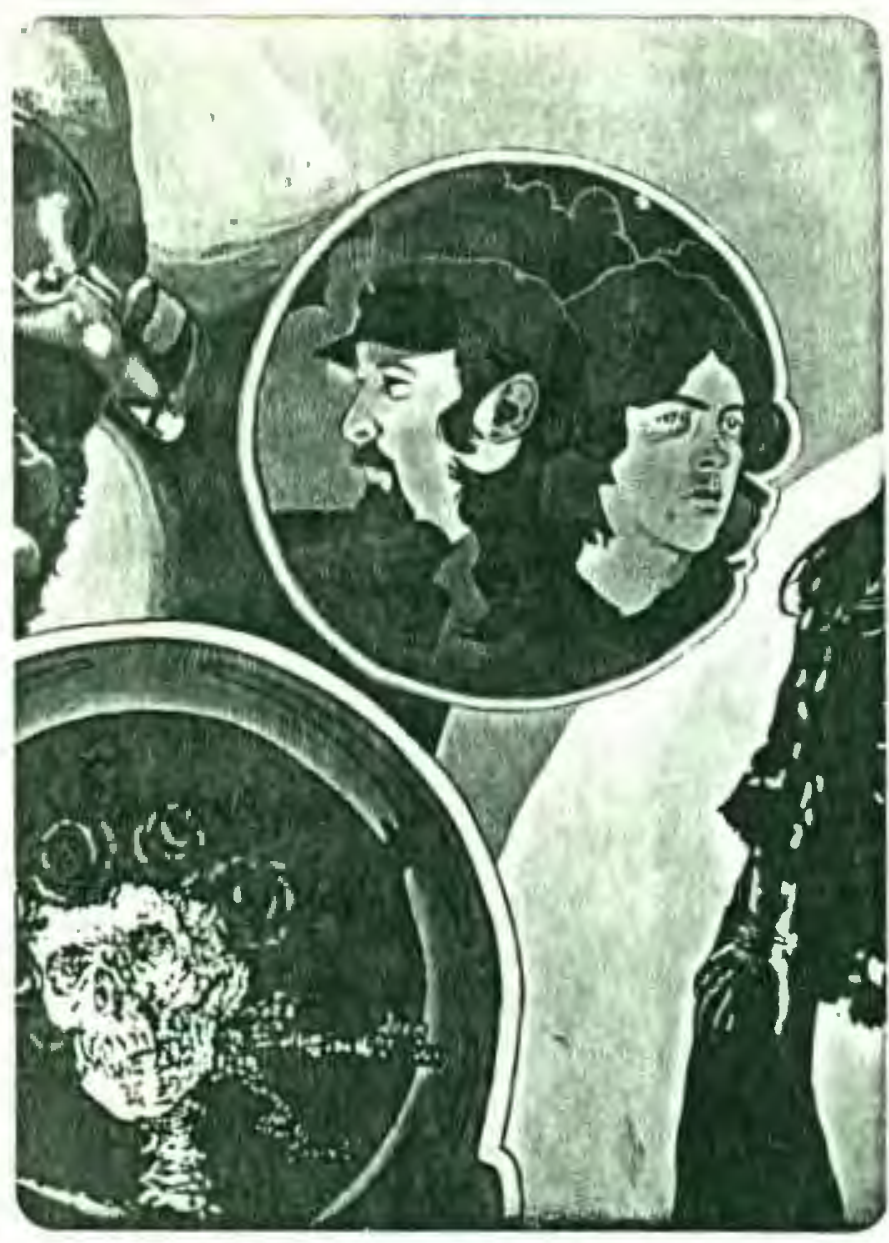

Eigure 7. Exterior Detail, Banana Records.

Bob Bailey has transformed a rather small and cramped space into a pleasing and directional motif. The Tower-Tote Restaurant at the First National Bank Tower is a good example of supergraphics used to give information and direction. 
Other First National Bank Tower supergraphics include a design by Mel Bogart of the Employee Dining Area under the direction of Charles Luckmann Associates, Los Angeles. Here simple bold shapes are used as design elements to transform the form and feeling of the wall.

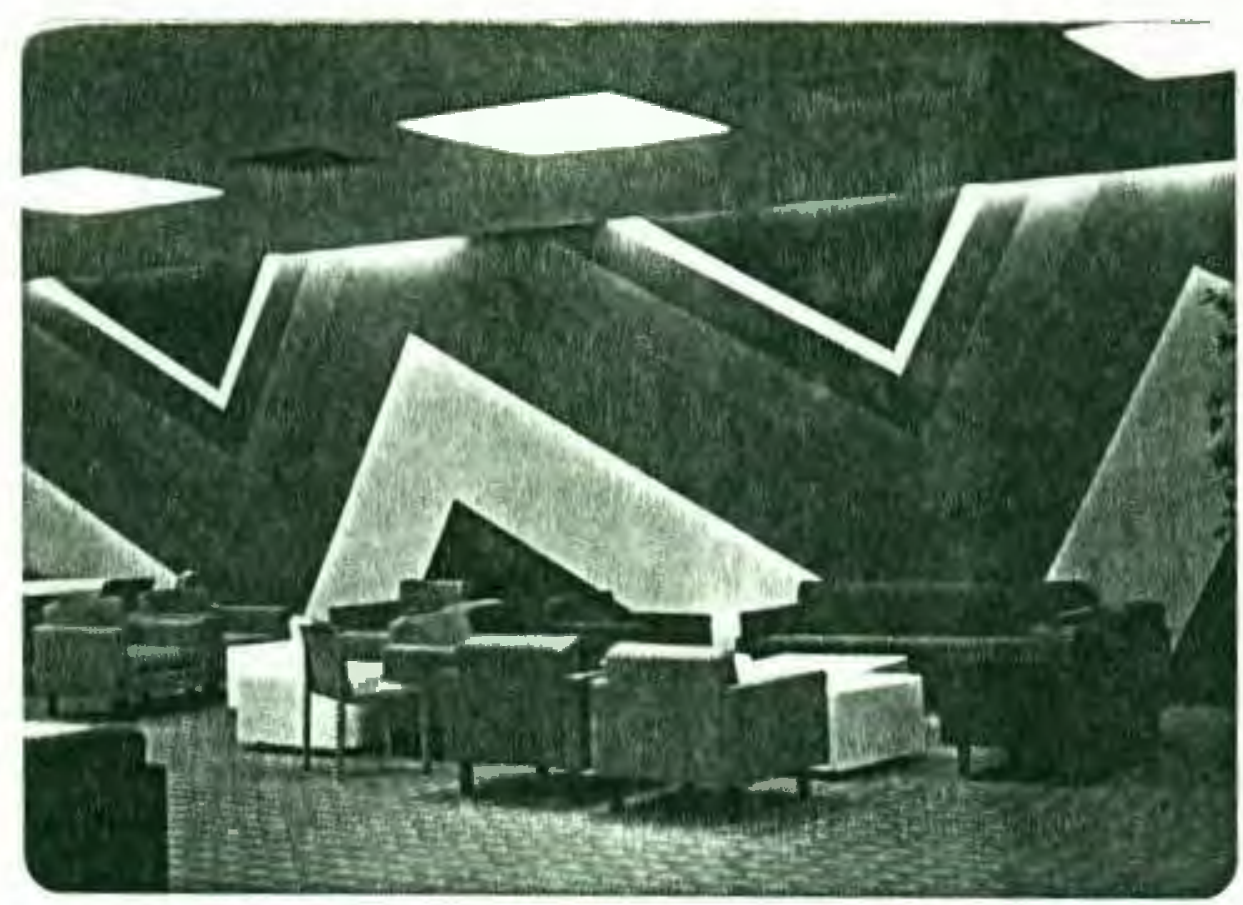

Flgure 10. Employee dining a rea. First National Bank Tower.

One very difficult problem in supergraphics is the transformation of long narrow halls into spaces that feel differently than maze passage ways. Sharon Rogers tackled this problem at The Manpower Offices, at Marylhurst Campus in Lake Osweg.o. 


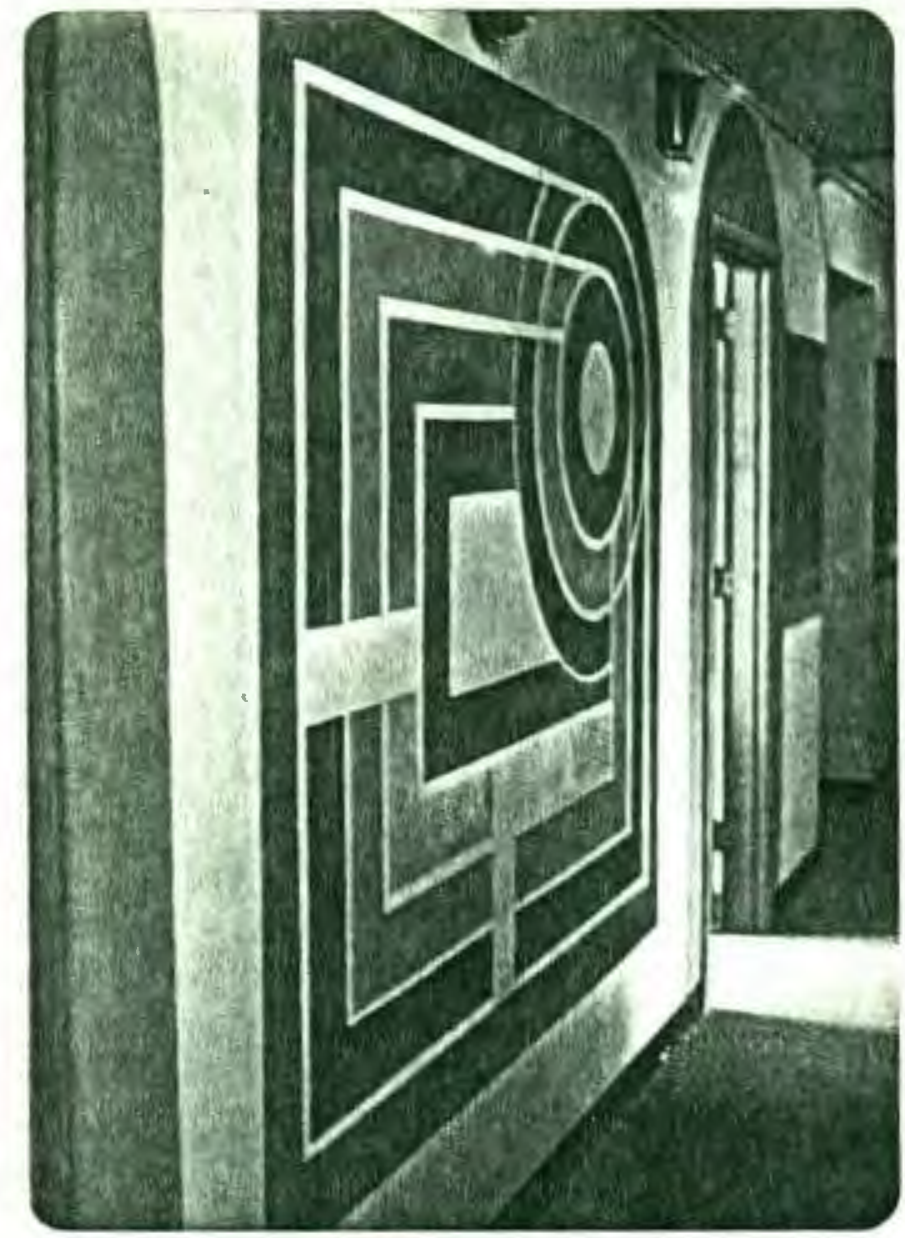

Figure 11. Interior, Manpower offices, Marylhurst Campus.

John's Landing, on Macadam in S.W. Portland, is an example of supergraphics used specifically to renovate old structures into desirable and attractive new ones. Bill Ruff, in conjunction with the architectural firm of Griggs, Lee and Ruff, designed the graphics with a bit of humor in mind. The entrance is graced with the word "enter" and rather whimsically invites the viewer to come inside and enjoy the various shops. 


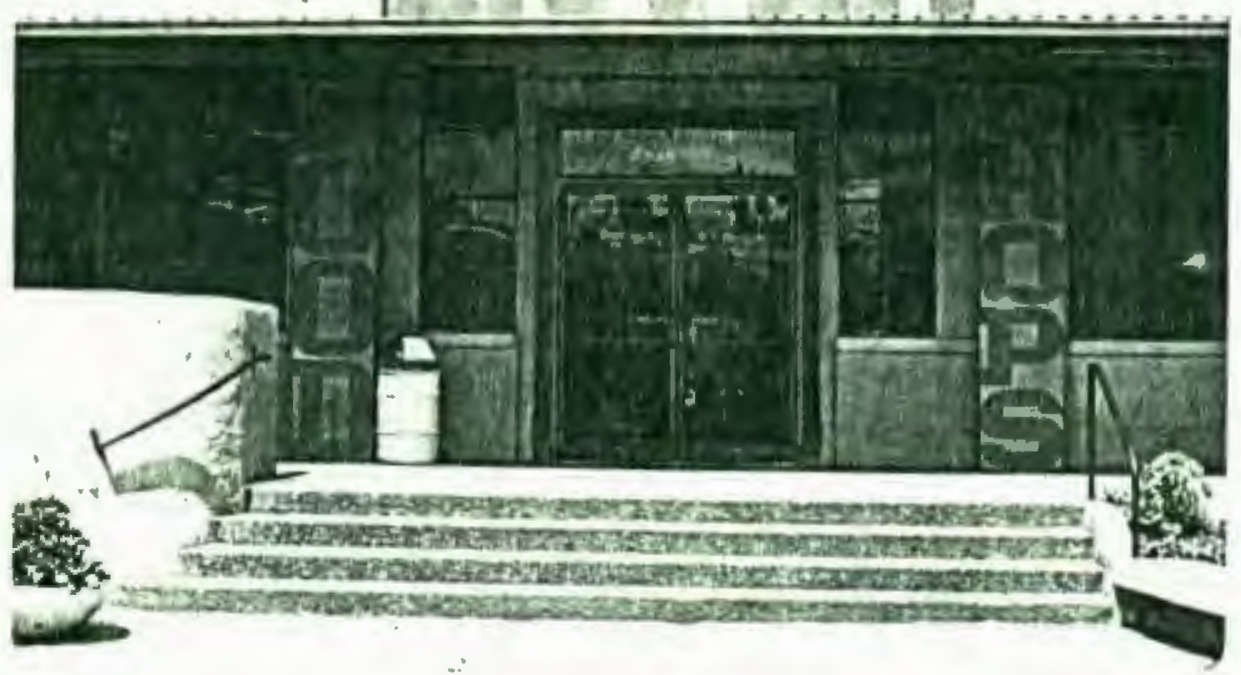

Figure 12. Entrance, John's Landing

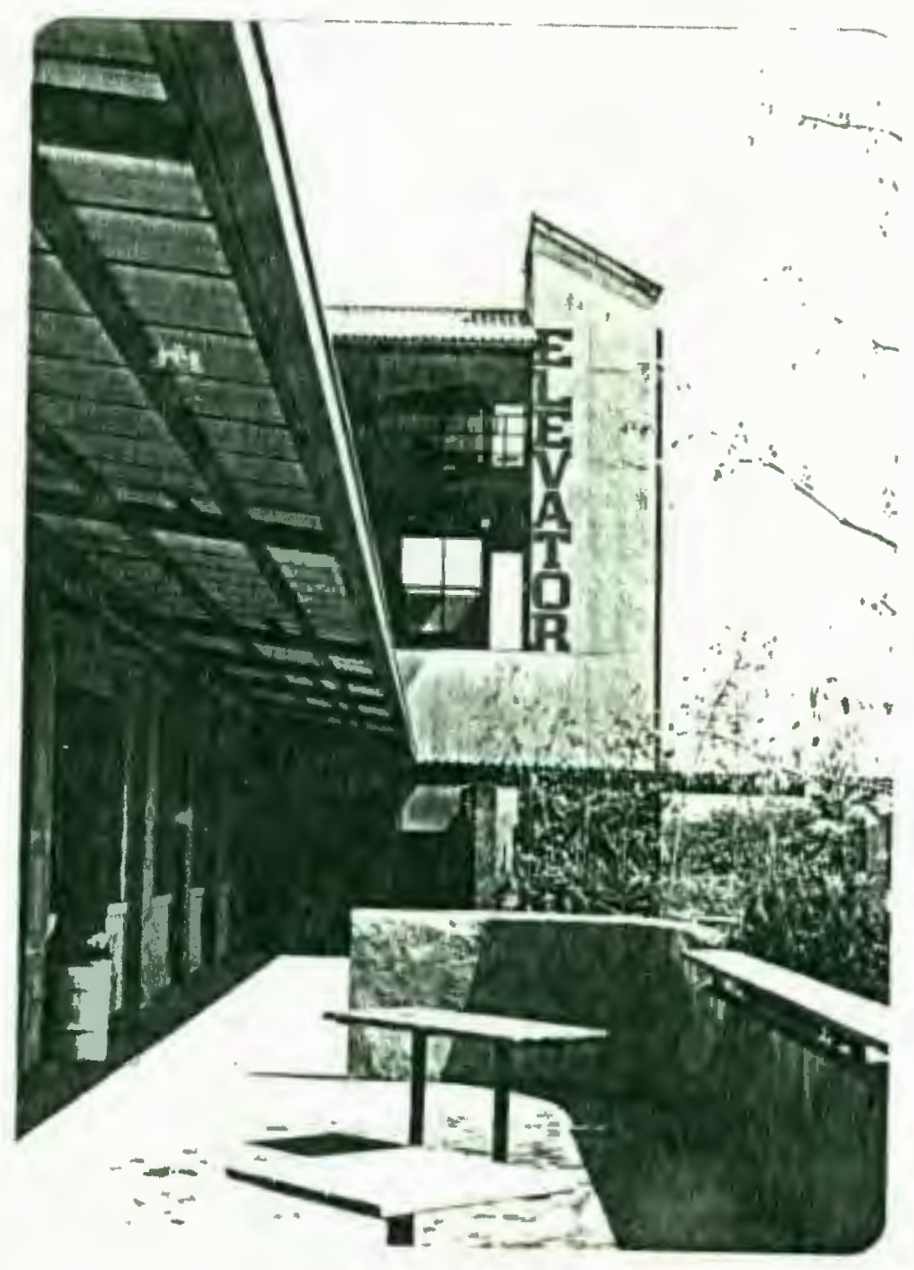

Figure 13. Exterior, John's Landing 
Lou Ocepek and twenty-five graphic art students from Portland State University have created some fascinating supergraphics at the Foster Hotel in North-west Portland. The Foster Hotel was previously an institutional-looking establishment occupled by senior citizens. The residents there can now enjoy the humorous and nostaglic works that grace the lobby and the alphabetical system that logically section off each floor.

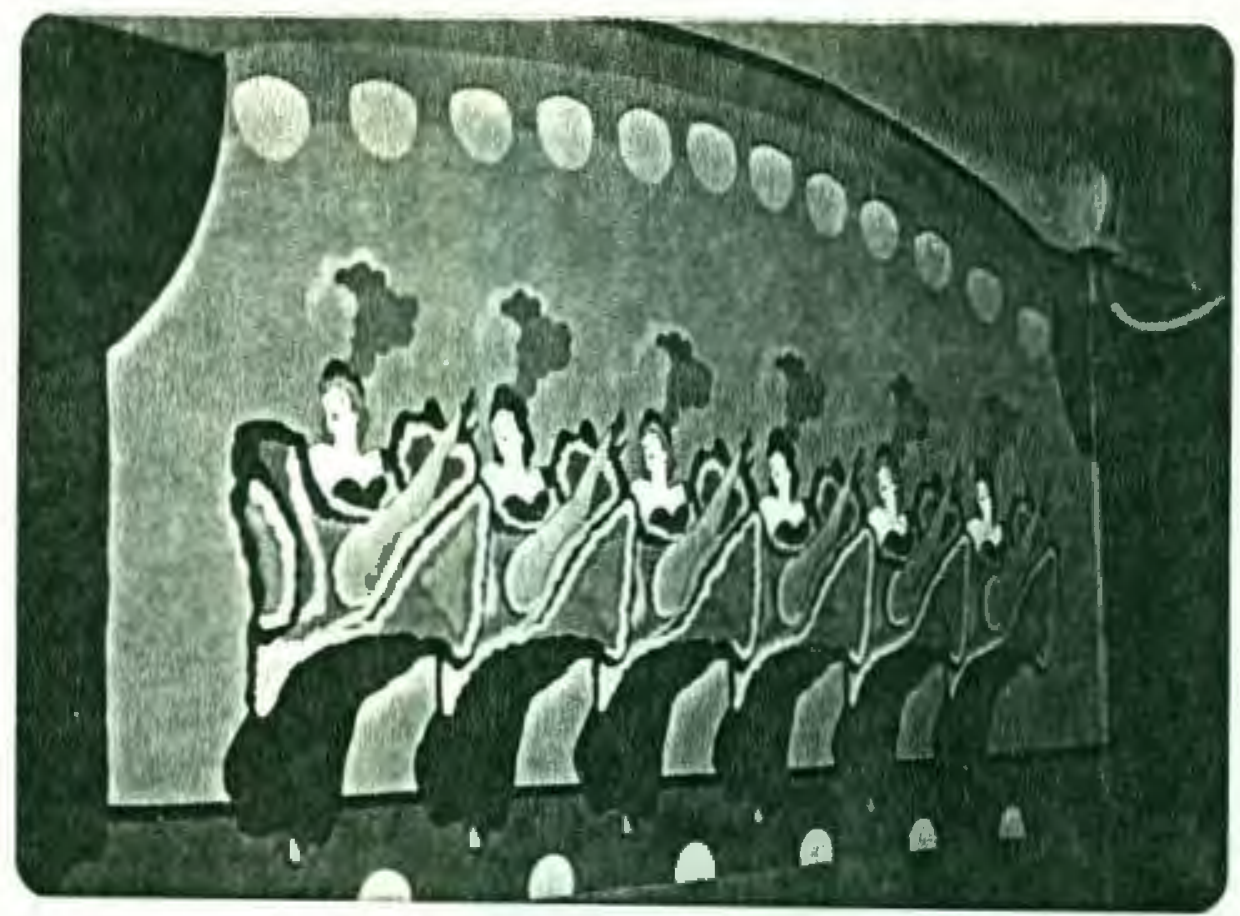

Figure 14. Lobby, Foster Hotel 


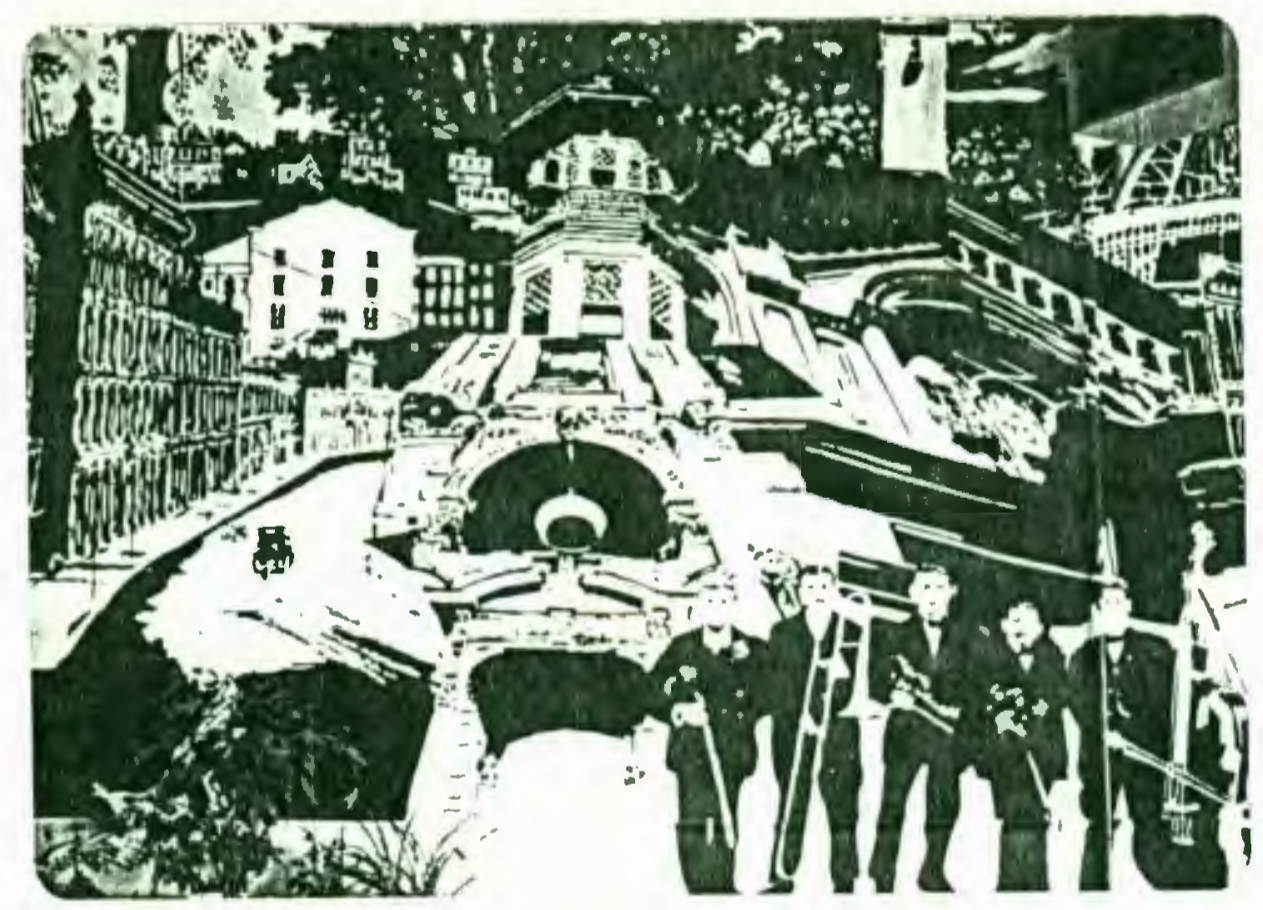

Figure 15. Lobby, Foster Hotel.

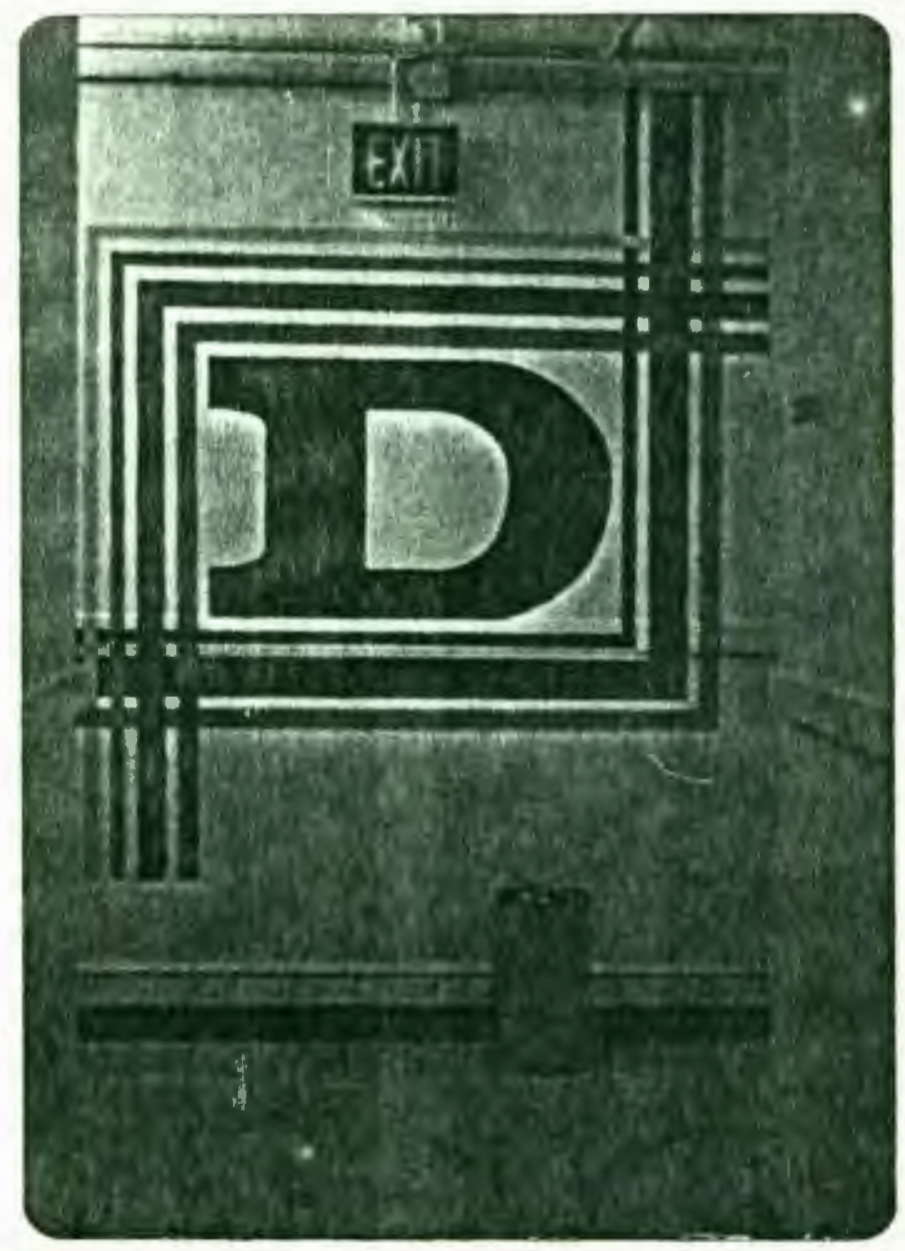

F1gure 16. Interior Hal1, Foster Hotel 
Dave Duncan is responsible for the strikingly-simple, yet effective design that transforms the long, blank industrial exterior of Hanna Industries into an exciting, eye-catching work of art. By repeating the shape of the Hanna Industries logo, Mr. Duncan has changed what was an anomymous building near McLoughlin Boulevard into a landmark. Anyone driving along the highway would have difficulty missing such a powerful and pleasing work.

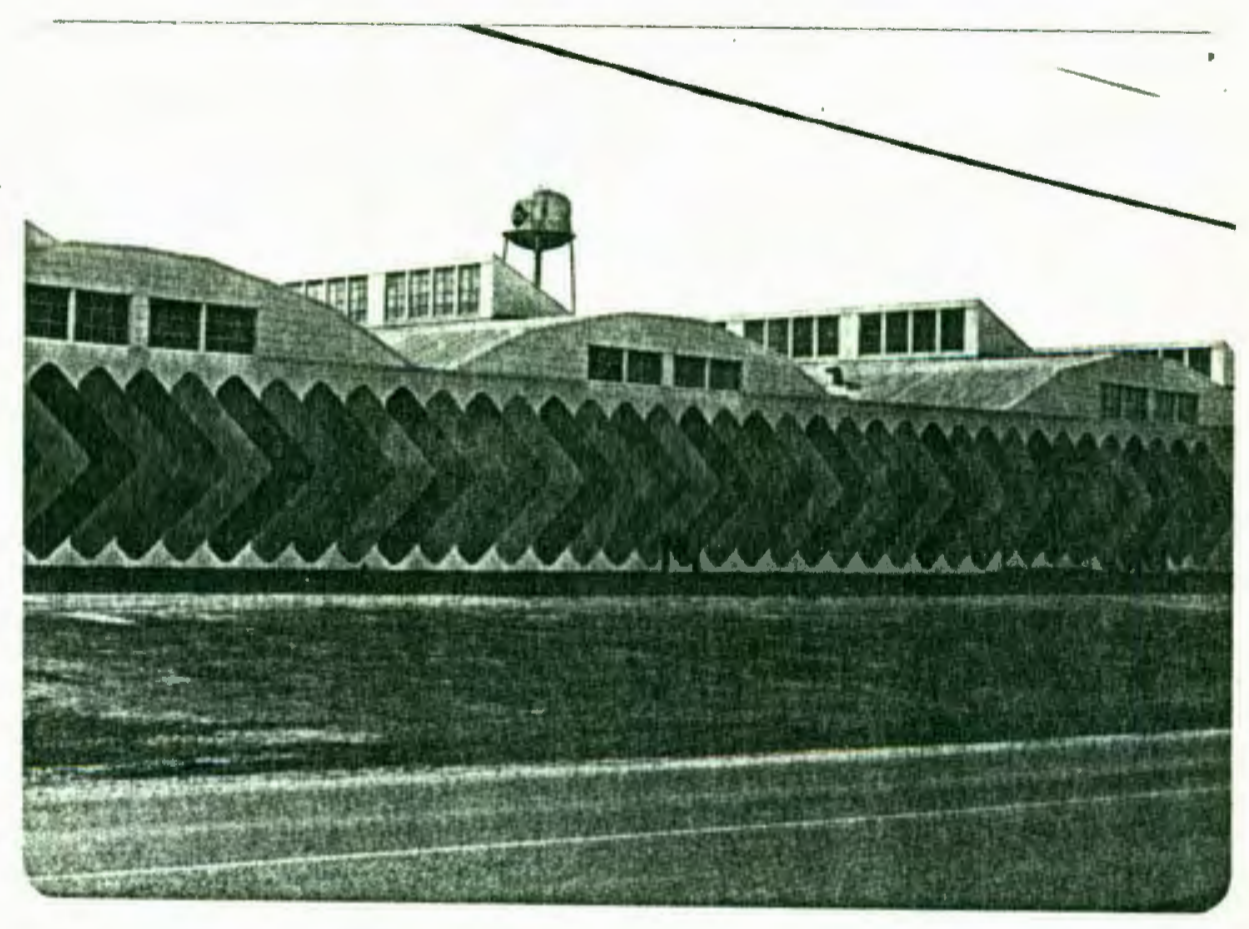

Figure 17. Exterior, Hanna Industries 


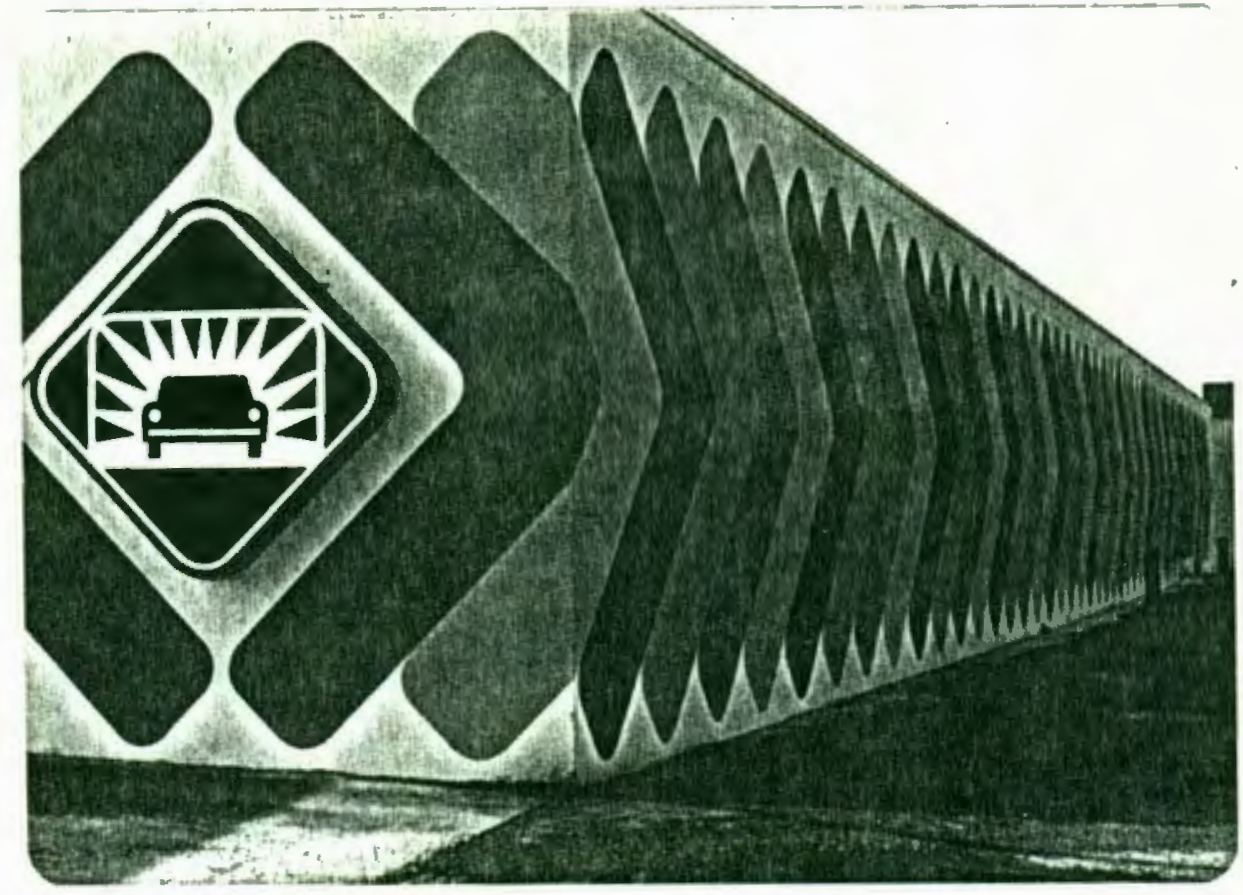

Figure 18. Exterfor, Hanna Industries 


\section{SUPERGRAPHICS IN PORTIAND SCHOOLS}

Various school systems throughout the Portland area offer widely differing approaches and attitudes towards supergraphics. Depending on the school, there are wholly student organized supergraphics, supergraphics developed strictly by professional artists or artists-in-residence, teacher-initiated supergraphics and a host of supergraphics that represent a combination of teacher, student and artist's efforts.

West Linn High School is representative of a teacher-directed, student-designed approach. Under the direction of Ms.Bocc1, students taking the supergraphics class work on mimeographed scale layouts of the area they are to convert to supergraphics. When the teacher and students agree on a design or combination of designs, they present it to the administration for approval. Upon approval, they place the scale drawing in an overhead profector, where 1t is blown up to exact size. Then students penc1l out the design and begin applying paint. Their directional supergraphics combines a doorway and wraps around a corner to make a trip to the library an easy and pleasing experience. The limited use of color and simple design increase readability and reduce distraction. 


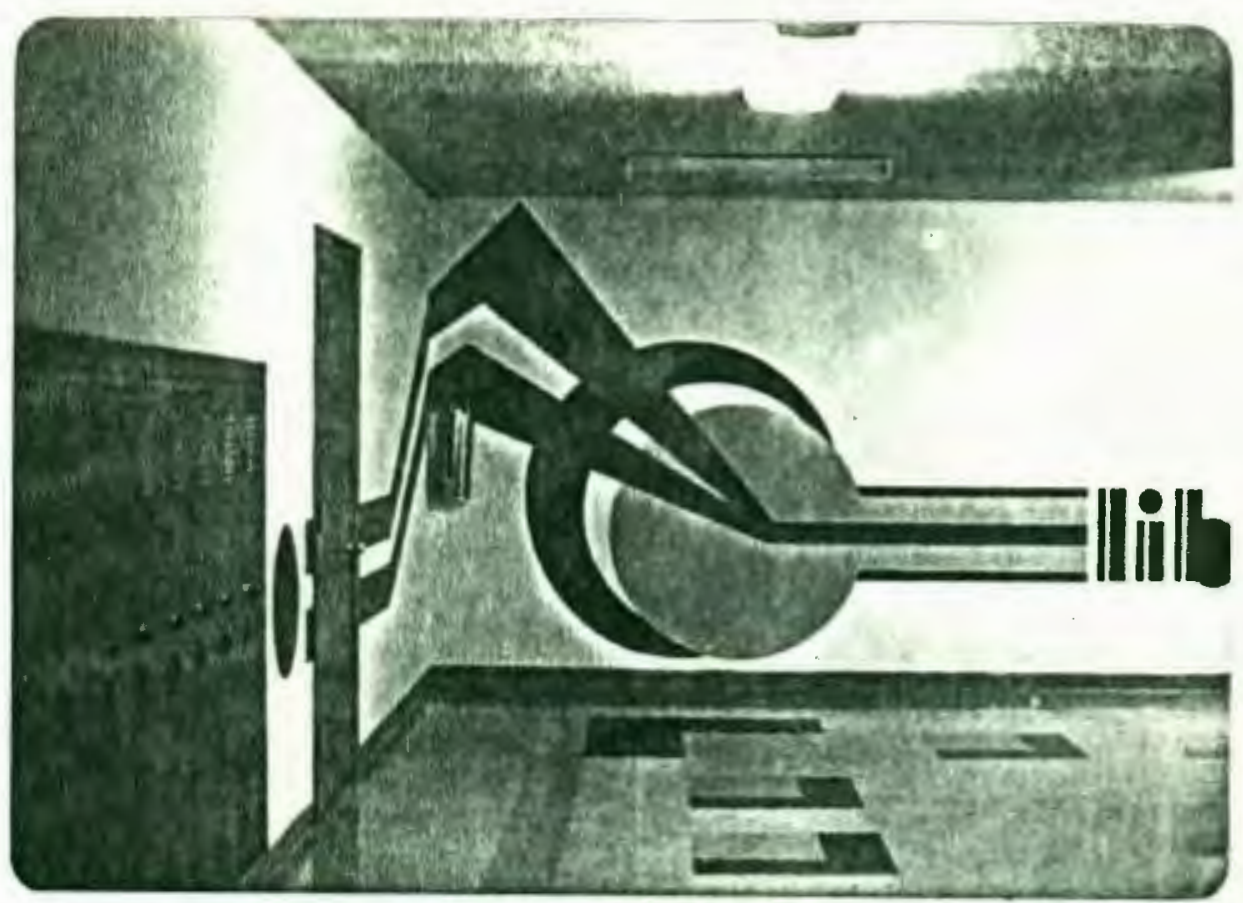

Figure 19. Interior, West Linn High School

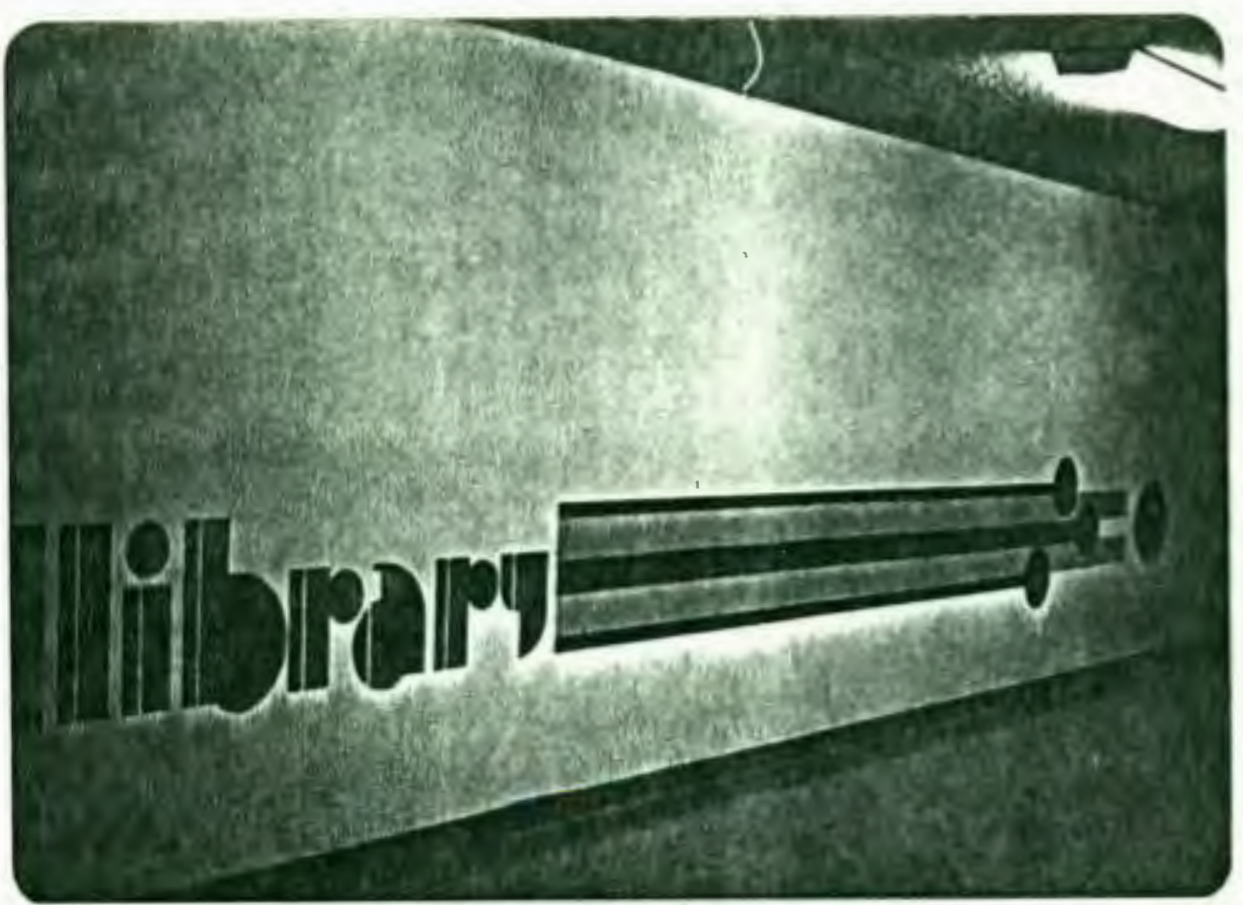

Figure 20. Interior, West Linn High School 
Gloria Urban directed the supergraphics at Waluga Jr. High School with a thematic scheme in mind. Colors were limited, in most cases, to the use of red, blue and brown. Simple bold designs and the use of the negative wall space to successfully interact with the painted shape resulted in what I feel to be one of the most successful supergraphics programs in Portland area schools. The area created between the painted surface and the wall is especially clean and enhances the crispness of the design.

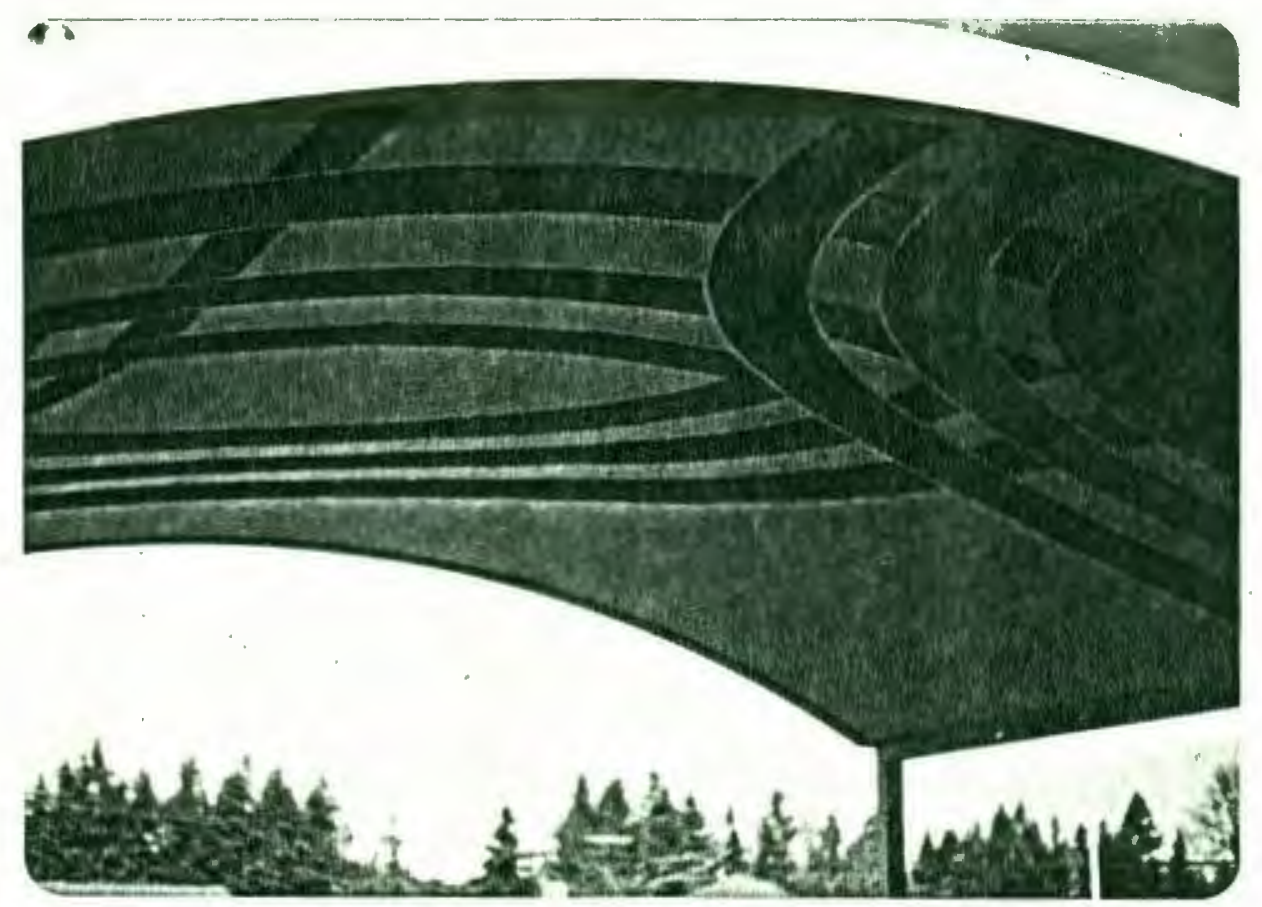

Figure 21. Entrance Arch, Waluga Jr. High School 


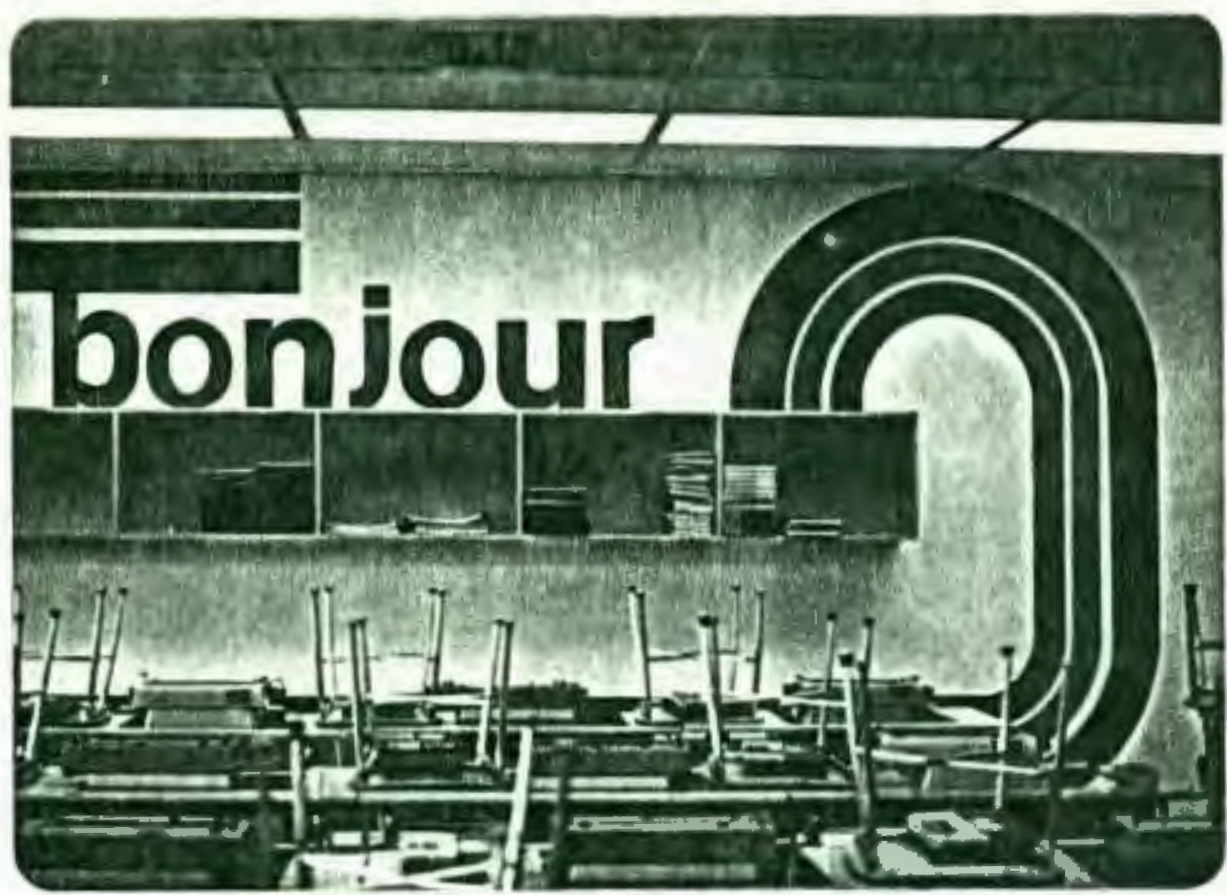

Figure 22. French Room, Waluga Jr. High School

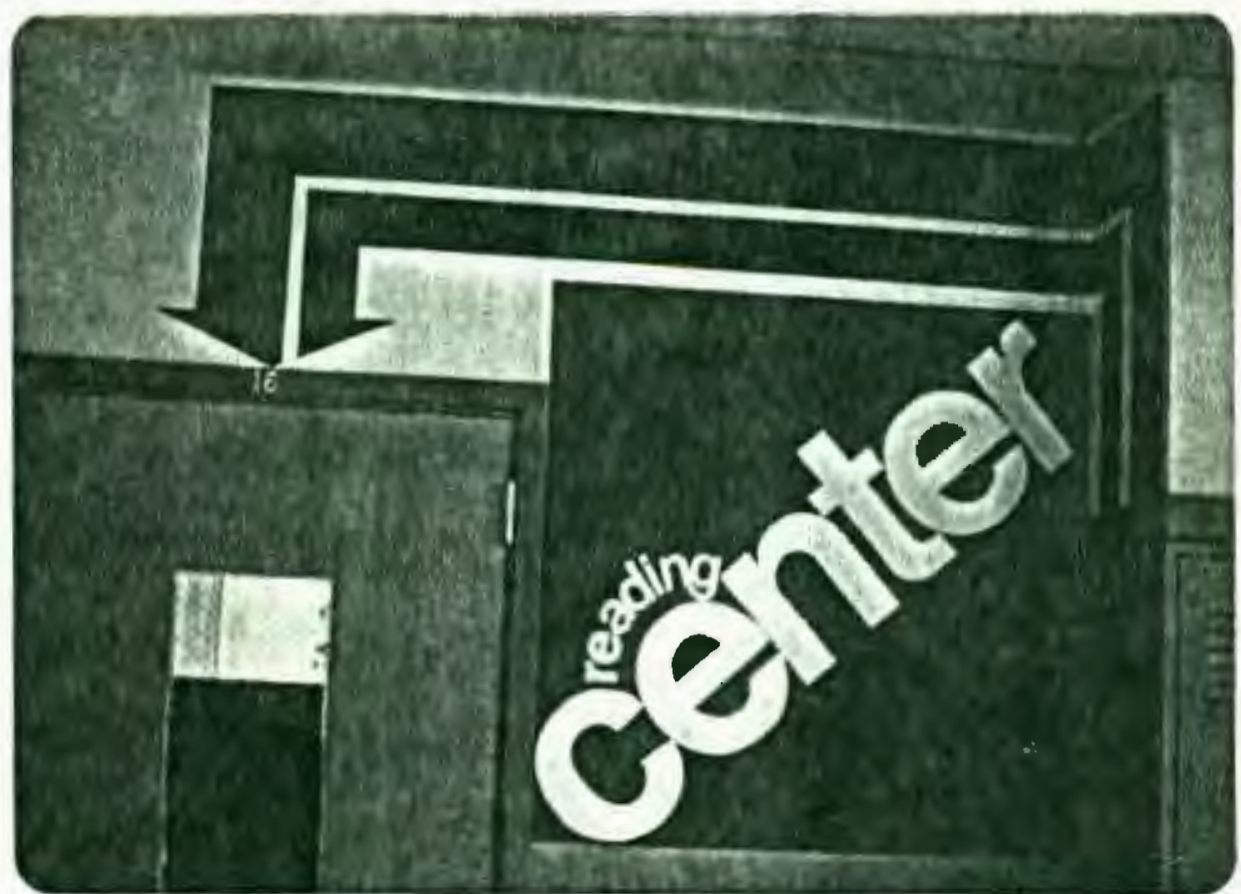

Figure 23. Reading Center, Waluga Jr. High School 


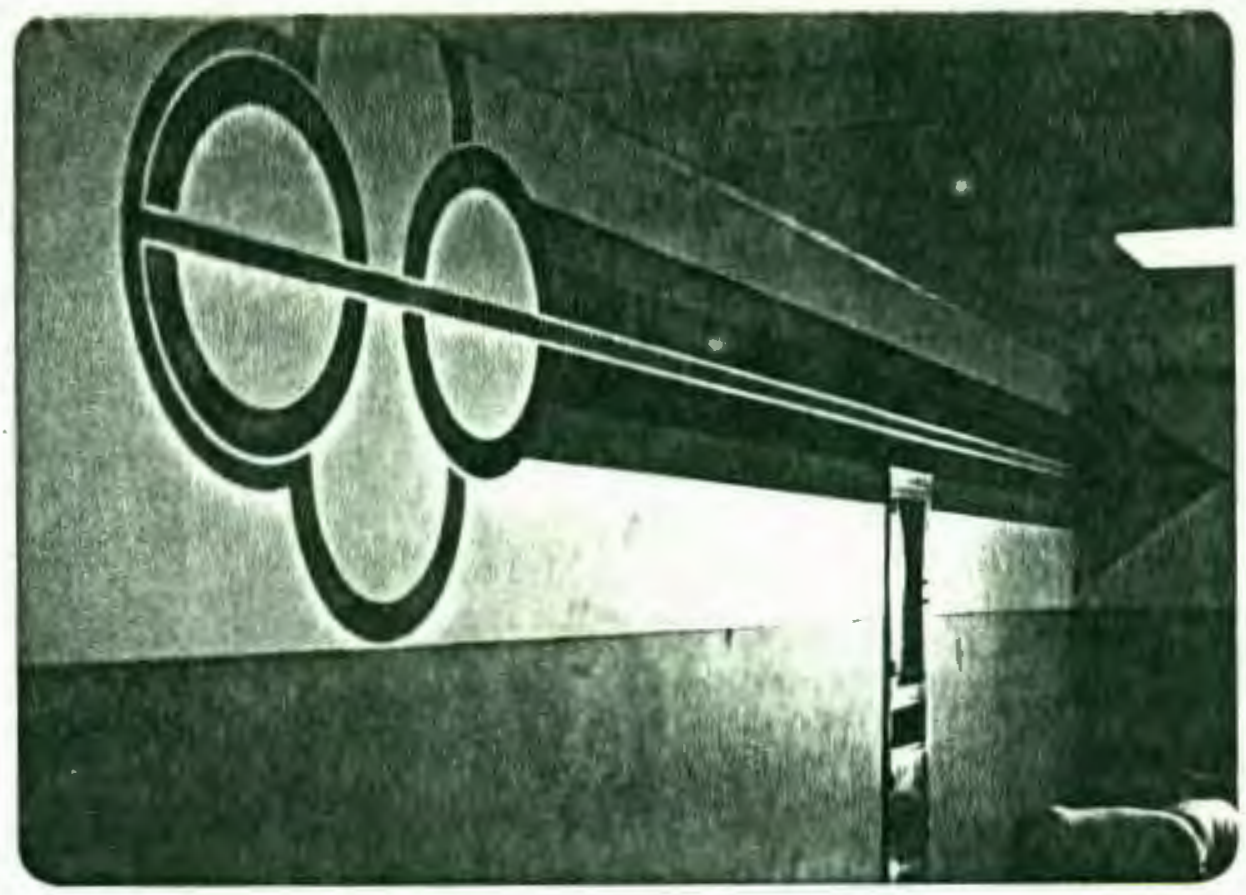

Flgure 24. Hallway, Waluga Jr. High School

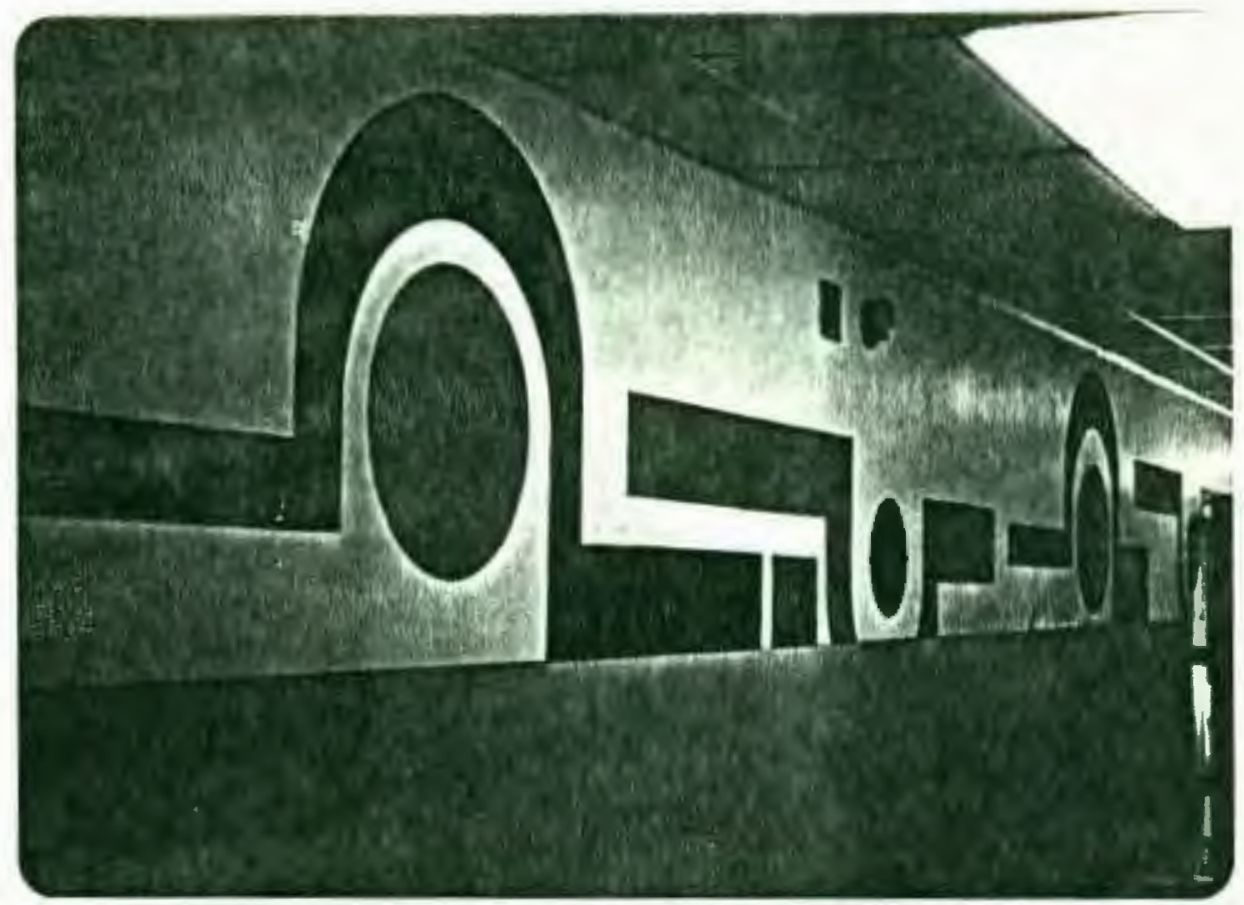

Figure 25. Hallway, Waluga Jr. High School 


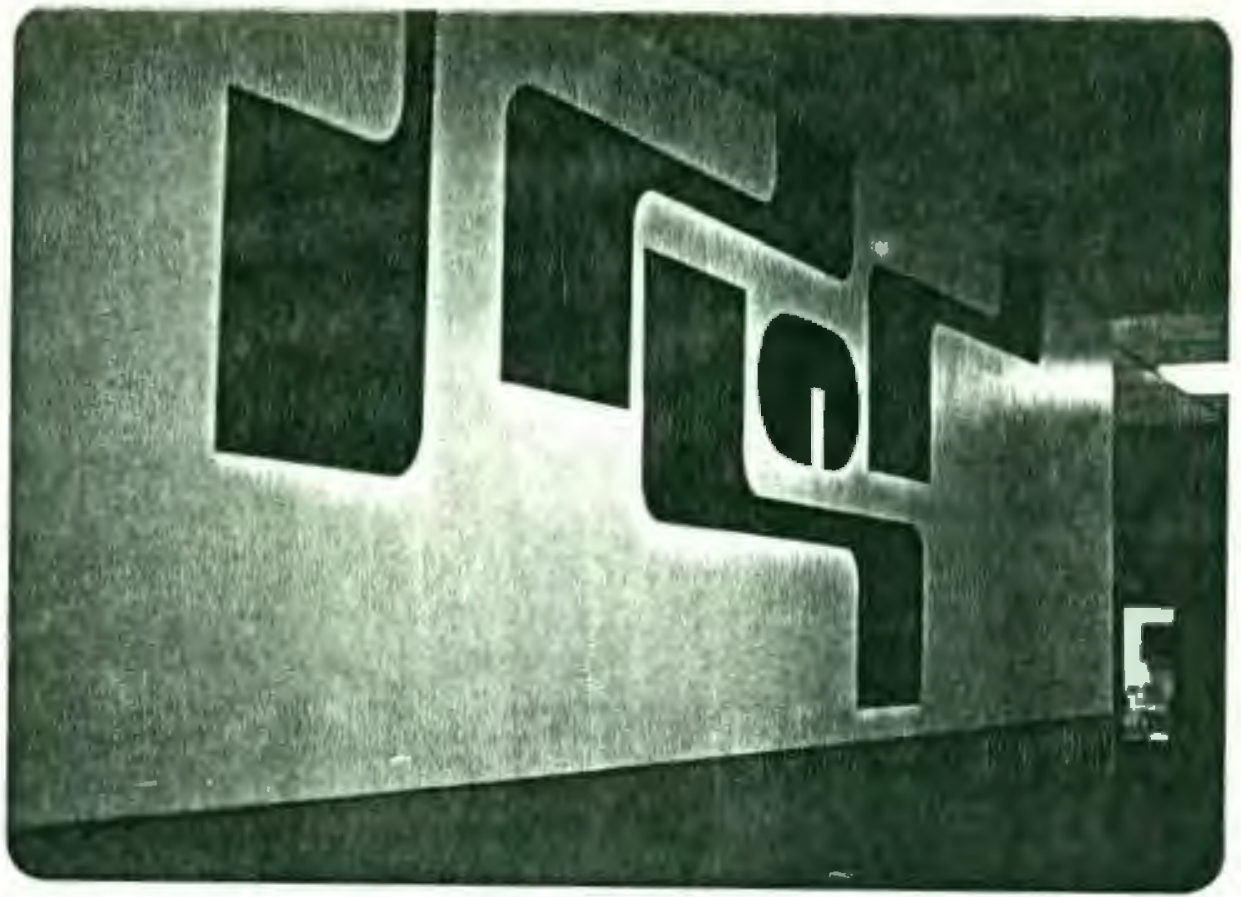

Figure 26. Ha11way, Waluga Jr. High School

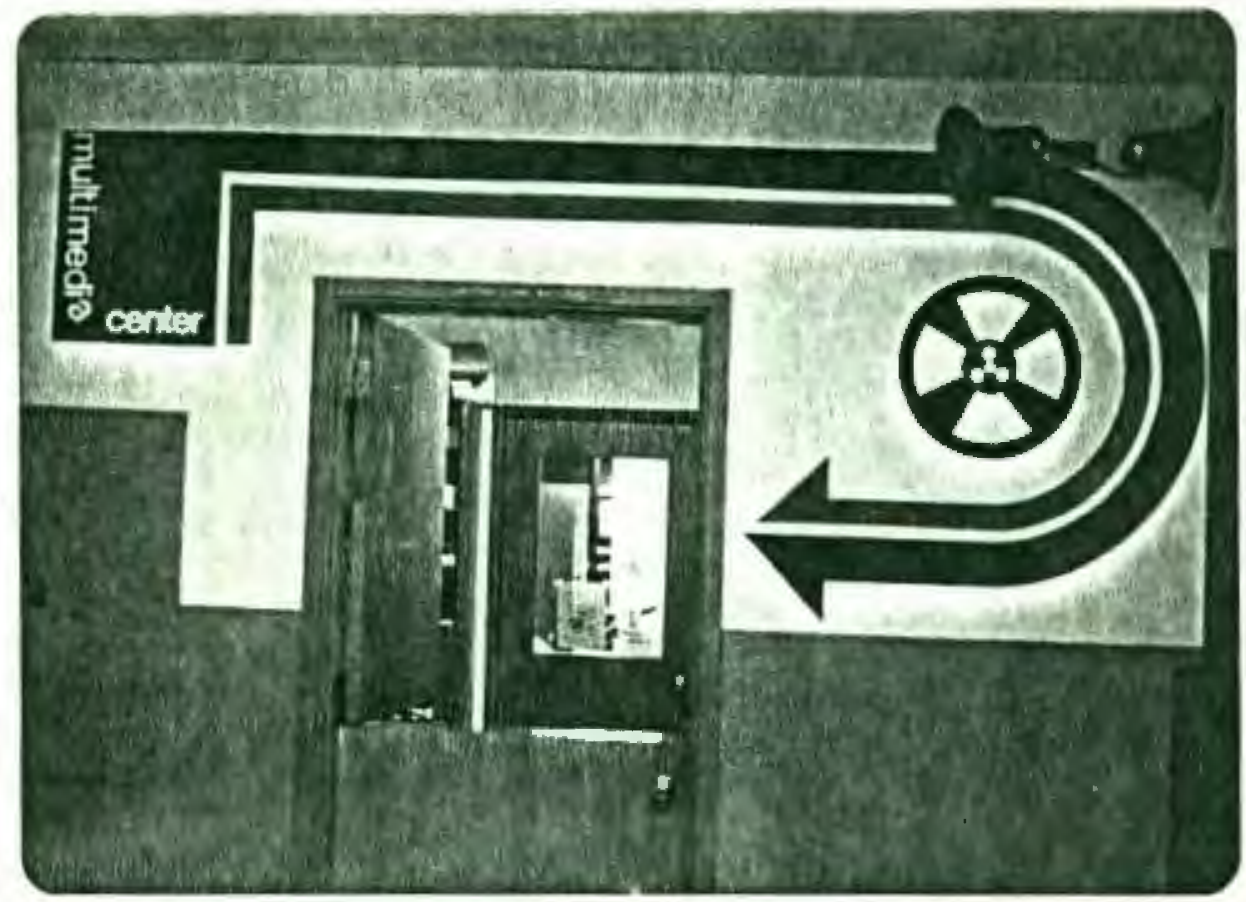

Figure 27. Multimedia Center, Waluga Jr. High School. 


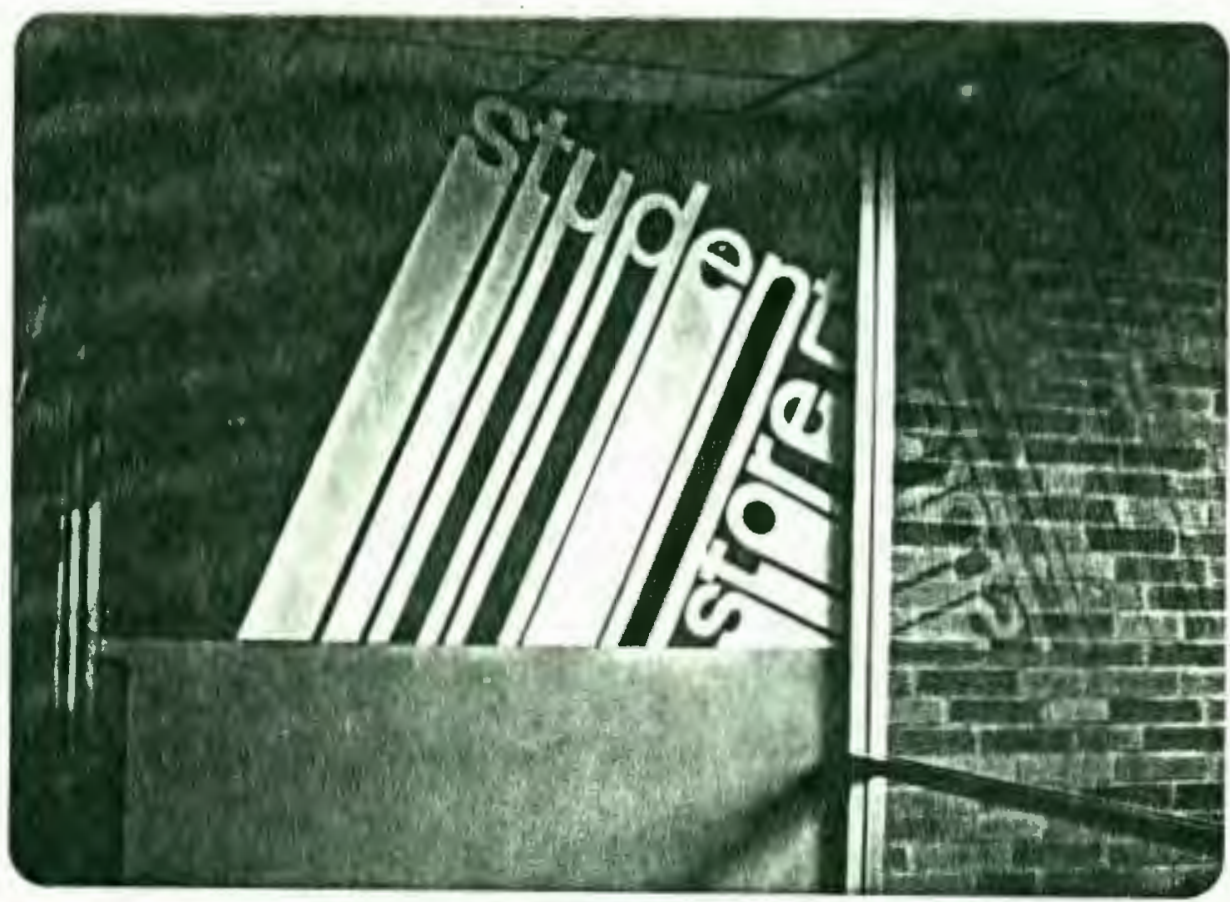

Figure 28. Student Store, Waluga Jr. High School.

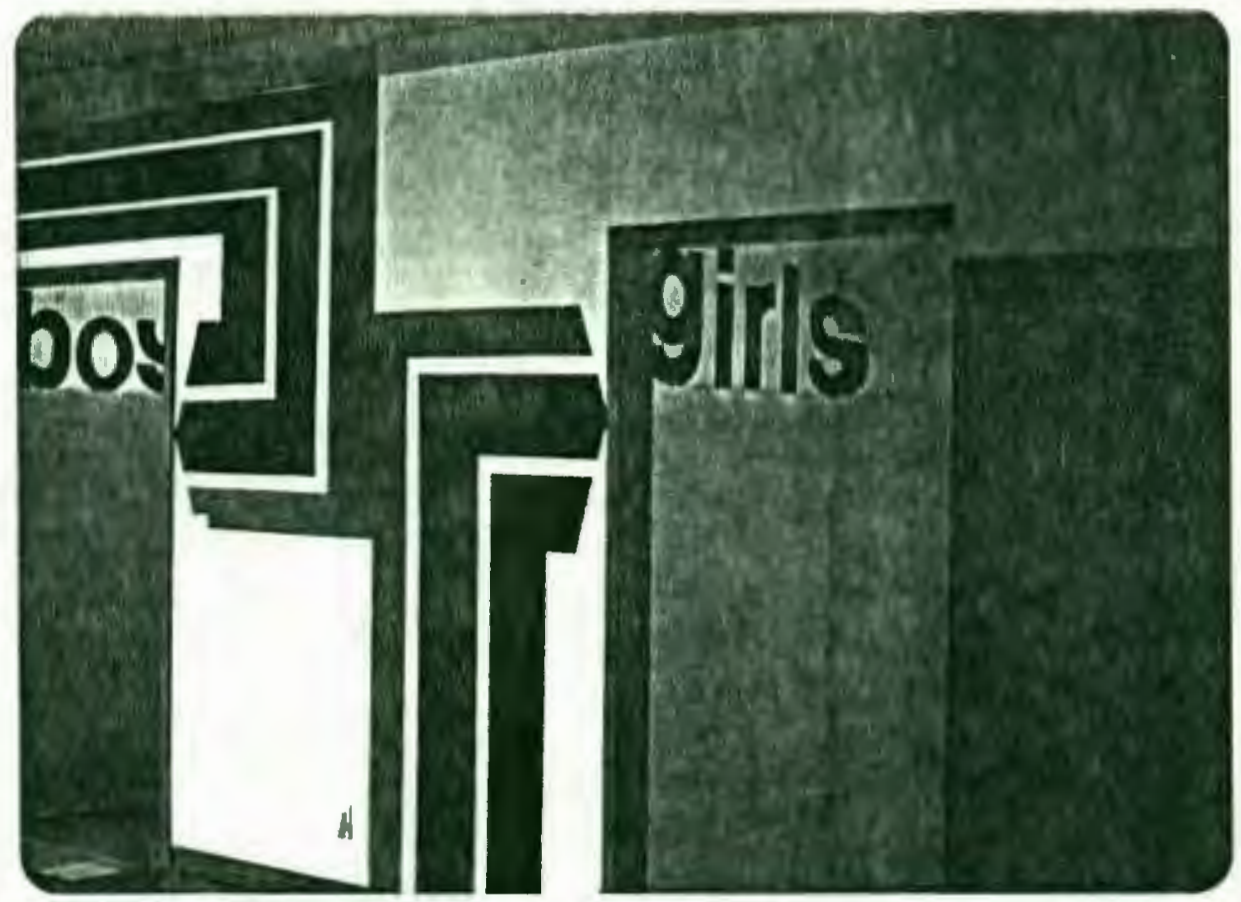

Figure 29. Student Rest Rooms, Waluga Jr. High School. 
Les Turpin is teaching supergraphics to students at Oregon City High School with an emphasis on the student-initiated approach. Mr. Turpin has gone to great pains to see that students get as much exposure to supergraphics as possible. He has excellent resource books avallable for student use as well as the laminated examples of professional supergraphics from magazines that he posts on the bulletin board. Before his students actually work on projects throughout the school, and in between projects, Mr. Turpin has them working on "blow-up" projects that he has devised. Administrative difficulties at Oregon City High School are at a miminum because of the age of the facility As a result, Mr. Turpin's students have already completed supergraphics projects at their resource center, home economics hallway, counseling, offices and on their library columns. Mr. Turpins's students use scale drawings with overhead projectors, in order to get the correct image on the wall. They also tape butcher paper backed with charcoal onto the wall, project the image, and trace with pencil. The result is a temporary carbon-like outline on a supergraphic scale.

Gary Pearson and Lanny Little are artists-in-residence at Benjamin Franklin High School who have implemented supergraphic programs with an emphasis on the bicentennial. This is especially appropriate in light of the name and architecture of the school. At Cleveland High School they have also worked on supergraphic programs with an emphasis on student participation, including 


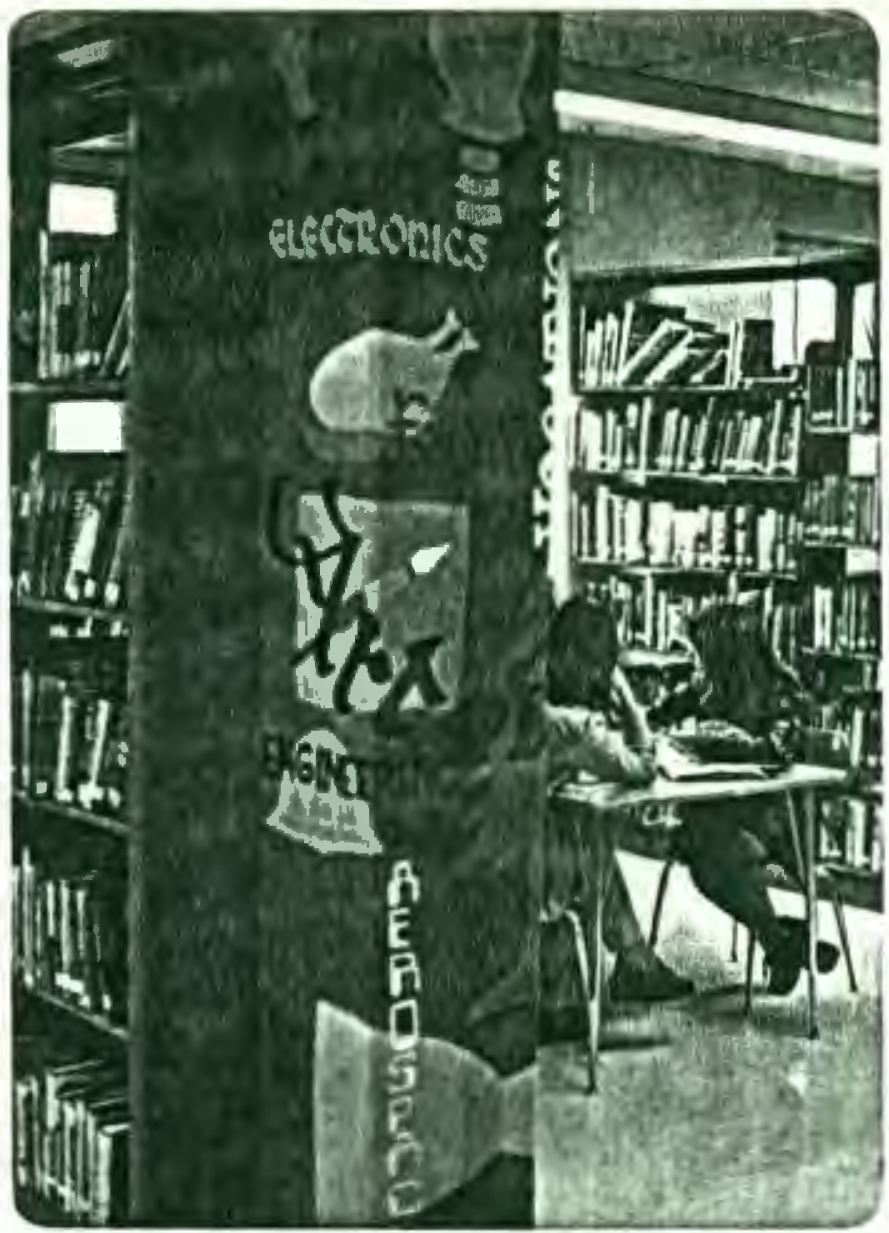

Figure 30. Library Column, Oregon City High School.

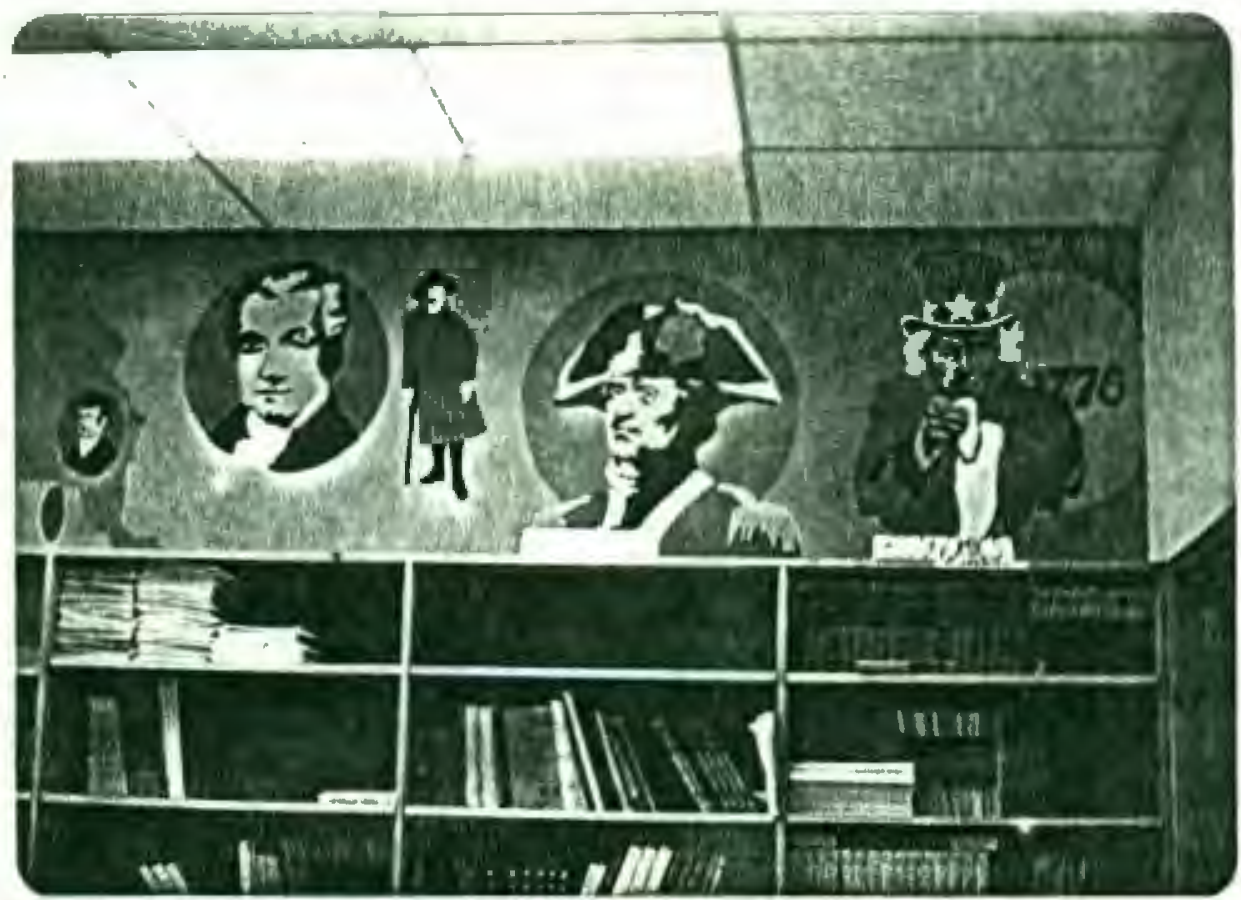

Figure 31. Resource Center, Oregon City High School. 
non-art students. Students were given a volce as to what type of design and theme would cover their walls, this sometimes ended in political controversy over subject matter between teachers, students and the administration. The results, as well as the art, were positive. The students had an opportunity to have a voice as to how they were going to manipulate an environment they spend time in every day.

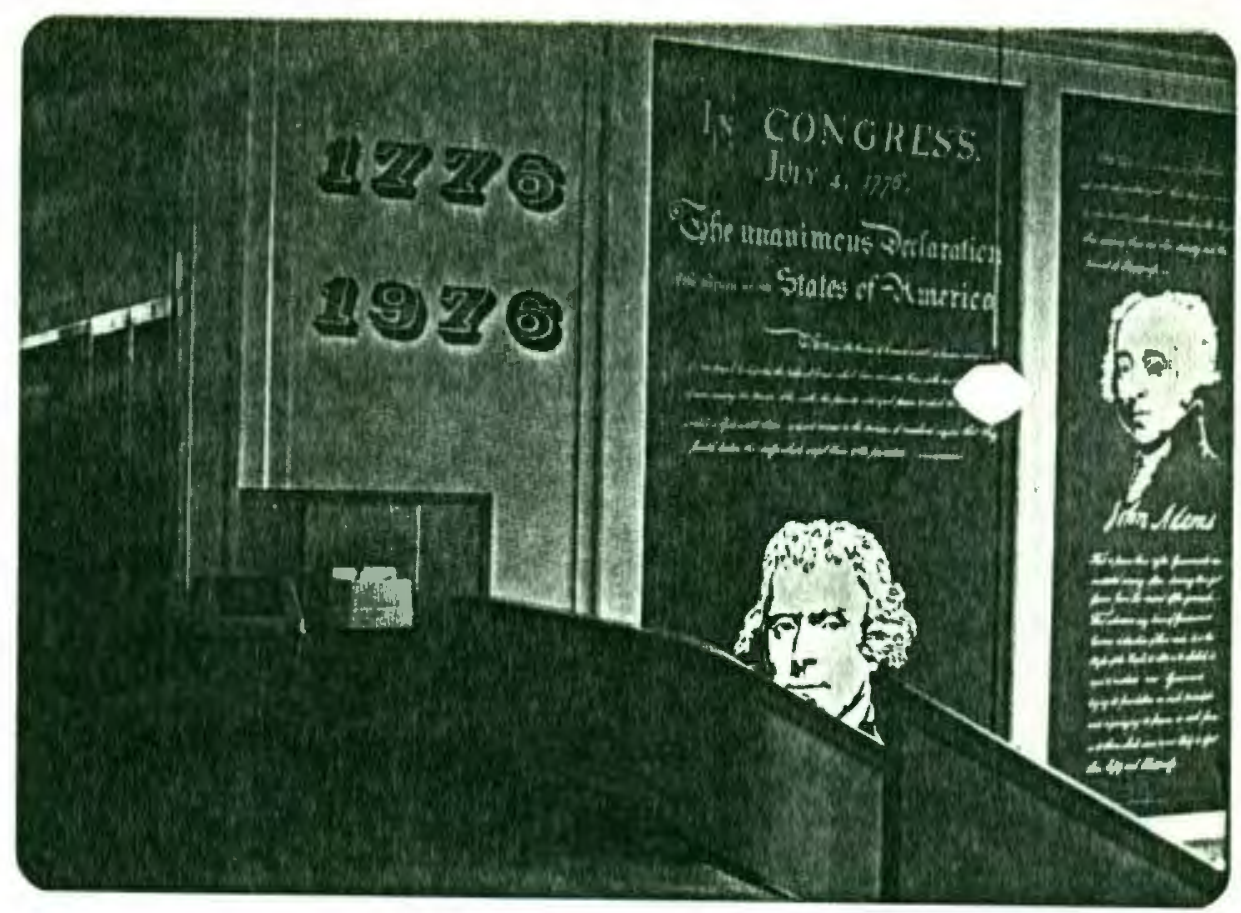

Figure 32. Interior, Frank1in High School 
Franklin created an outstanding supergraphics project based on important figures in the history of art on the art wing. Using simplified blow-up images of artists and their works, one can see the development of art from Glotto to Warhol. Mr. Garnett has also created a giagantic supergraphics project at Washington High School based on a bicentennial theme.

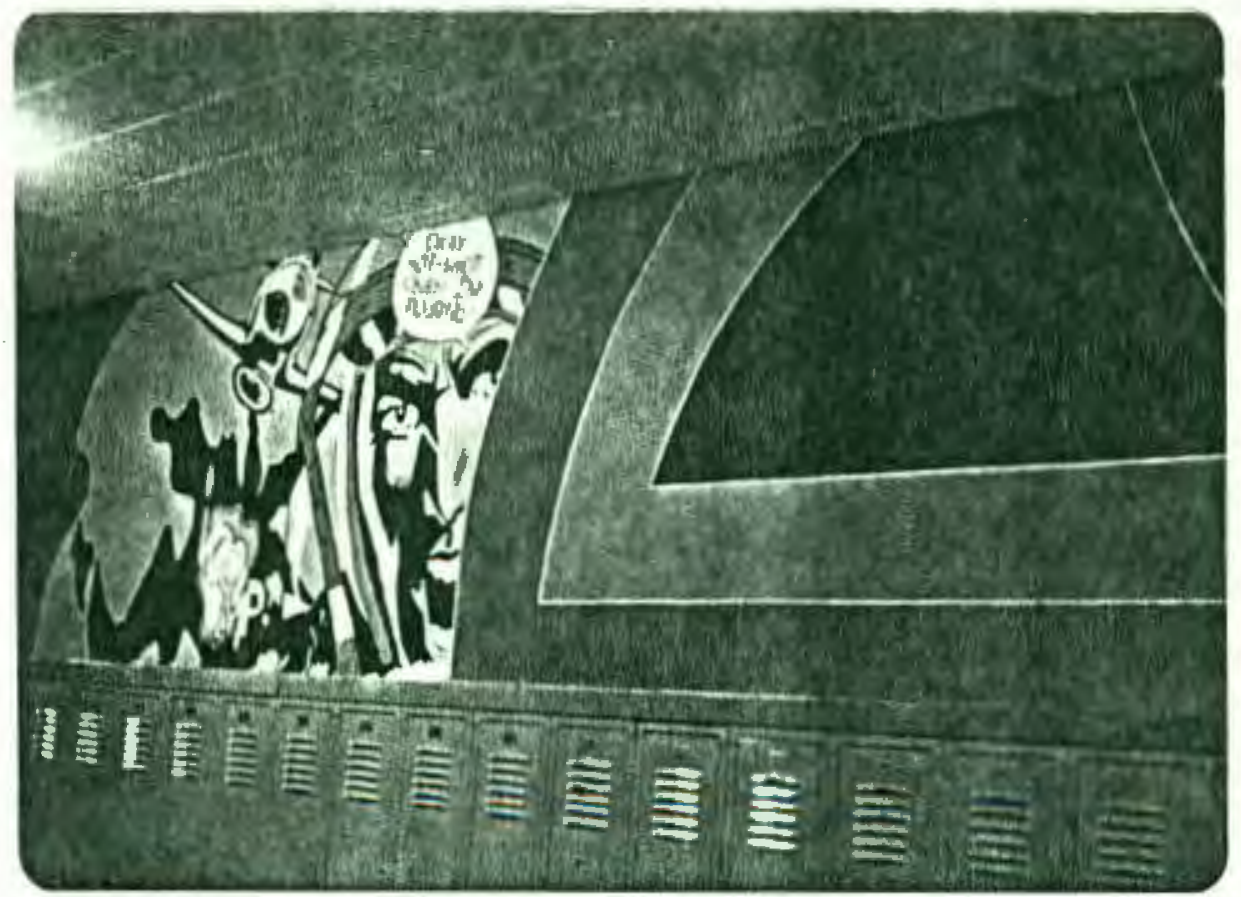

Figure 33. Interior, Franklin High School 


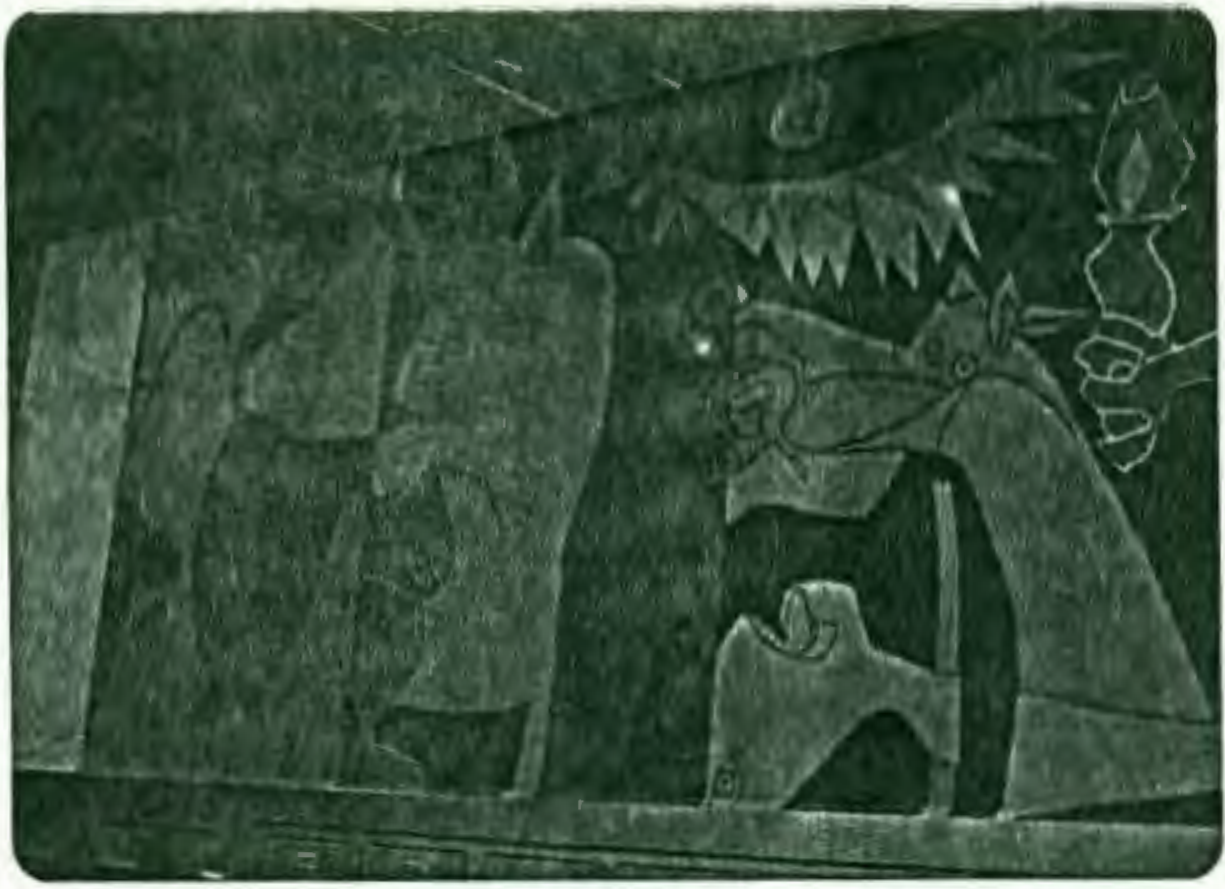

Figure 34. Interior, Franklin High School

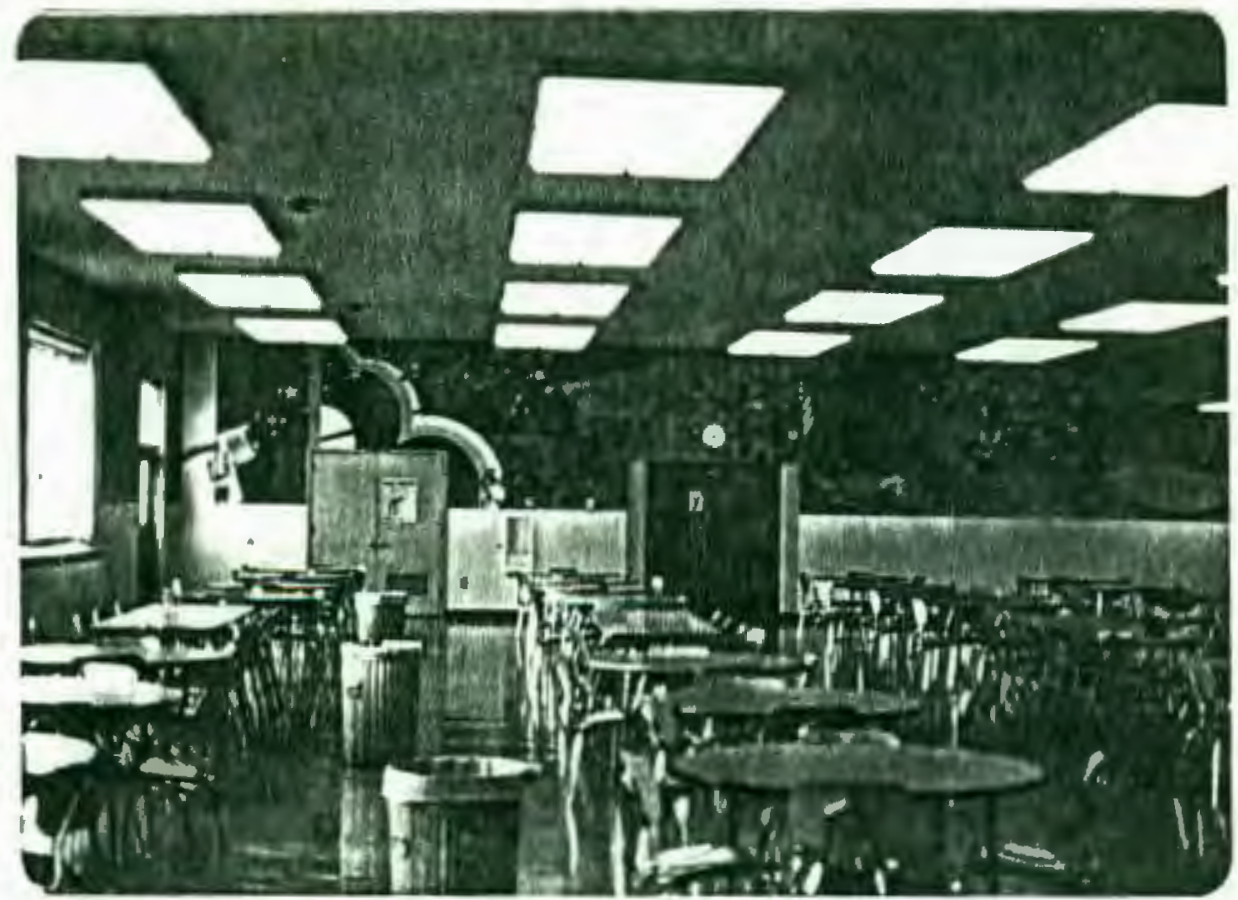

Figure 35. Cafeteria, Washington High School 


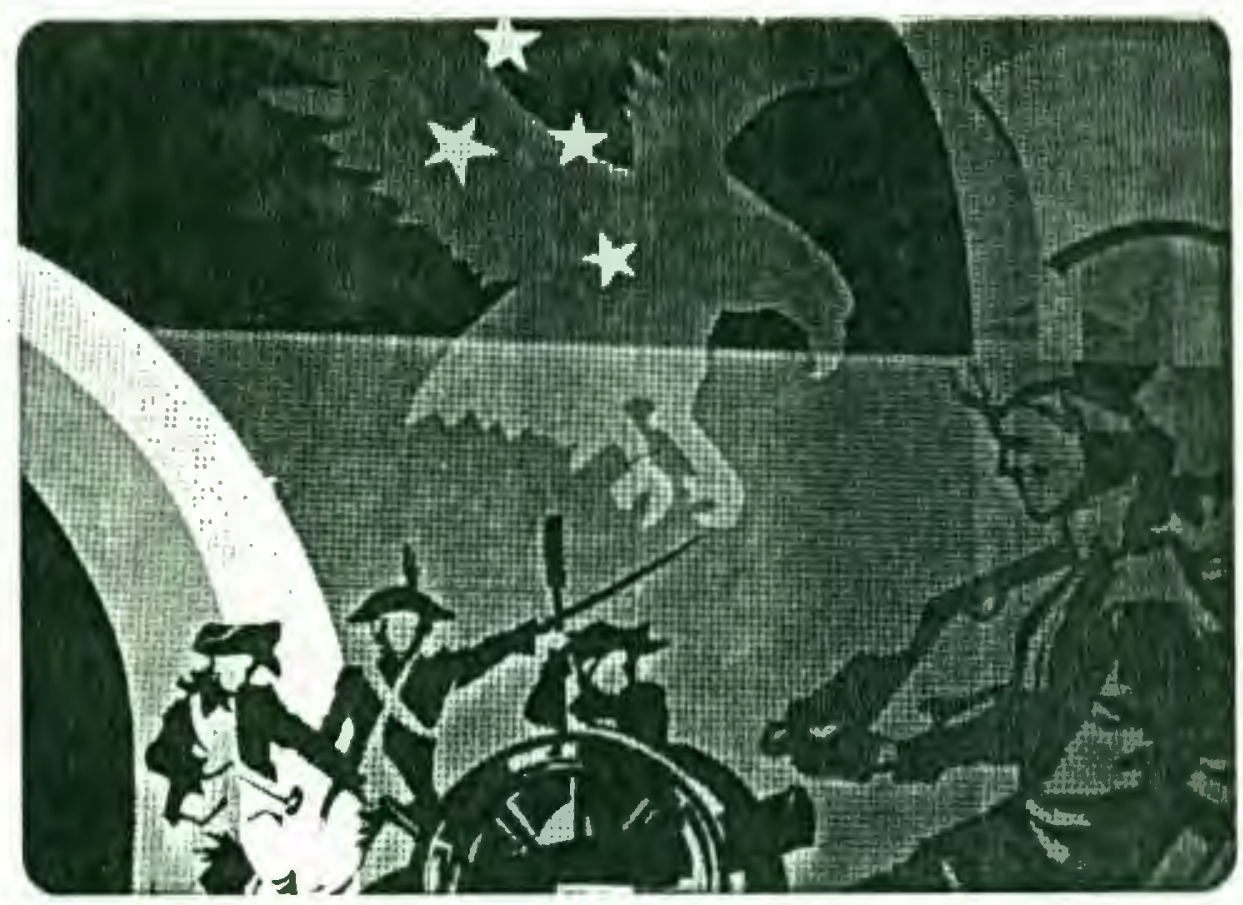

Figure 36. Detail, Washington High School

Gary Pearson and Lanny Little are currently in progress on a supergraphics project in front of Franklin High School's automotive center. Using a super-realistic approach they hope to have the automobile literally leaving the wall. 


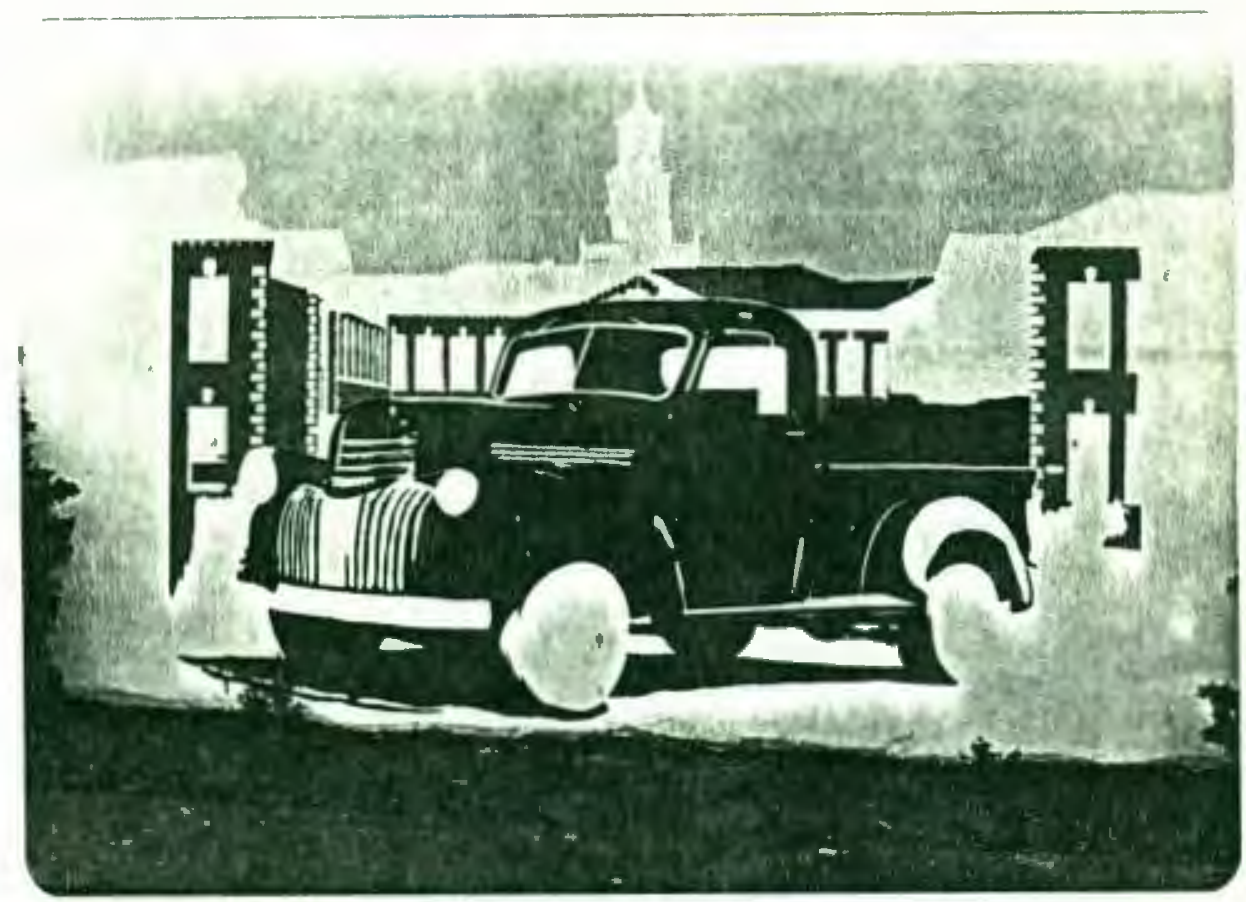

Figure 37. Auto Shop Exterior, Franklin High School

John Storrs has created an interesting mural-supergraphics project at Lakeridge High School using a combination of modeled forms and the flat, crisp images more often seen in supergraphic projects. 


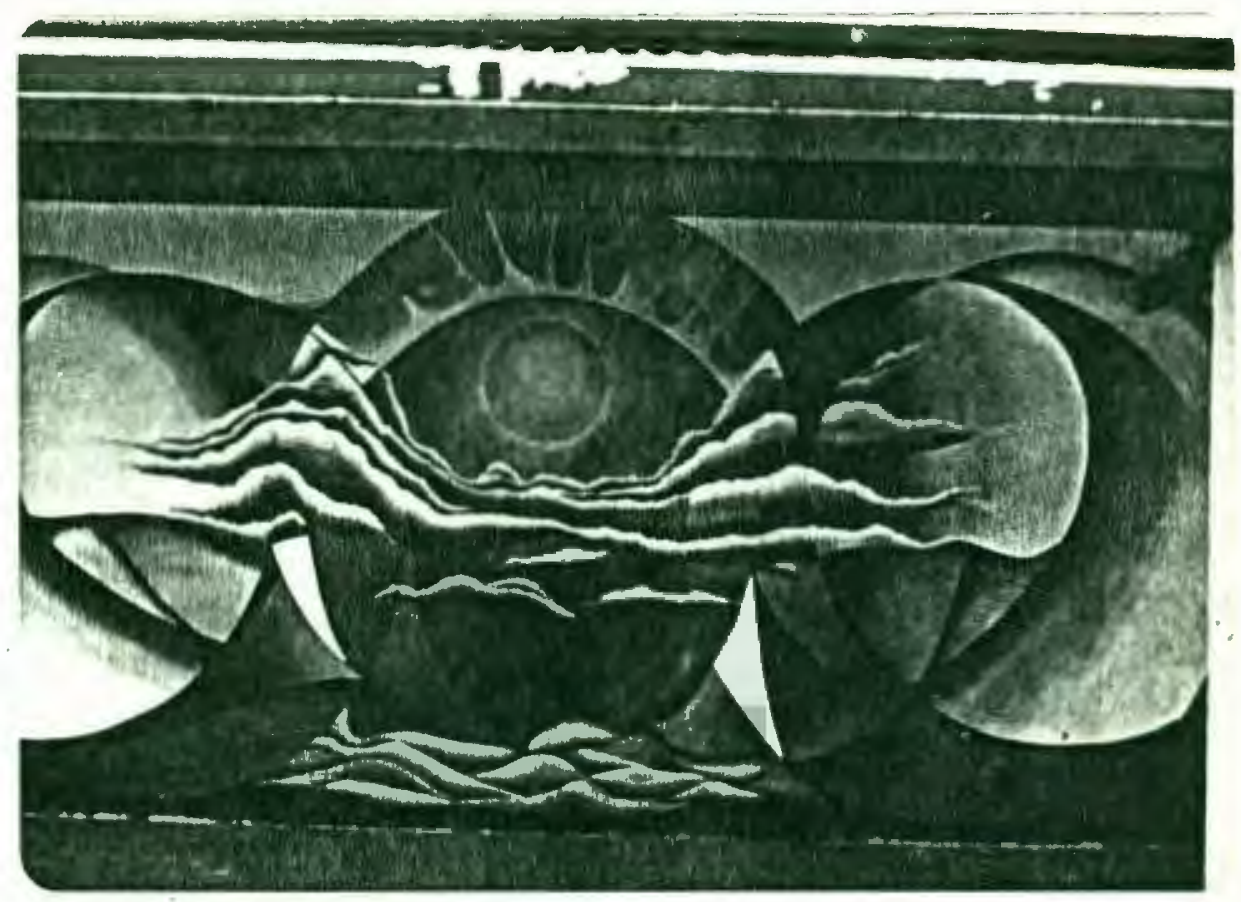

Figure 38. Exterior, Lakeridge High School

Supergraphic programs in the public schools are, in my view, one way students can creatively change their environment to sult their needs. It also affords them the opportunity to experience a large scale group project that has some relationship to the world around them. I find it gratifying that supergraphics can personalize not only the art room but the building that surrounds it. 
FOOTNOTES

1. Eliza Kruck, "Take a Tour of Portland's Supergraphics" Northwest Magazine, The Oregonian Publishing Company (March 28,1976.) Pg. 12.

2. Propper, "Architectural Spaces That Comminicate" Print (Jan/Feb 1974) Pg.66.

3. Orth, Maureen, "Schlock is Beautifu1" Newsweek (March 8, 1976) Pg. 52. 
A LIST OF WORKS CONSULTED

Blake, Peter. God's Own Junkyard. Canada: Hold Rinehart and Winston, 1964.

Cataldo, John W. Graphic Design-and Visual Communication. Penn.: Scranton International Textbook Co., 1966.

Ewa1d, William R. Street, Graphics. Virginia: American Soclety of Landscape Architects Foundations, 1972.

$\checkmark$ Glaser, Milton. Graphic Design.: New York: Overlook Press, 1973.

Gluck, Felix. World Graphic Design. New York: Watson Gupt111, 1969.

$\checkmark$ Marcus, Aaron. "Making Israel Visible" Print (Sept. - Oct.1973), $54-61$.

Propper, Robert and Elman, Dorothea. "Architectural Spaces That Communicate" Print (Jan. - Feb. 1974), 66 - 70.

Romotsky, Jerry. "California Street Scene: Wall Writing in L.A." Print (May - June 1974), $60-65$.

Trieb, March. "California Street Scene: Getting the Message in Berkeley" Print (May - June 1974), 66 - 69.

Trieb, March. "Cockta11s" Print (Jan. - Feb. 1974), 54 - 61. 